\title{
Alkaline Cleaner Replacement for Printed Wiring Board Fabrication
}

Federal Manufacturing \& Technologies

S. E. Goldammer,

S. E. Pemberton, and

Qt

D. R. Tucker

KCP-613-5926

Published April 1997

Topical Report

Approved for public release; distribution is unlimited.

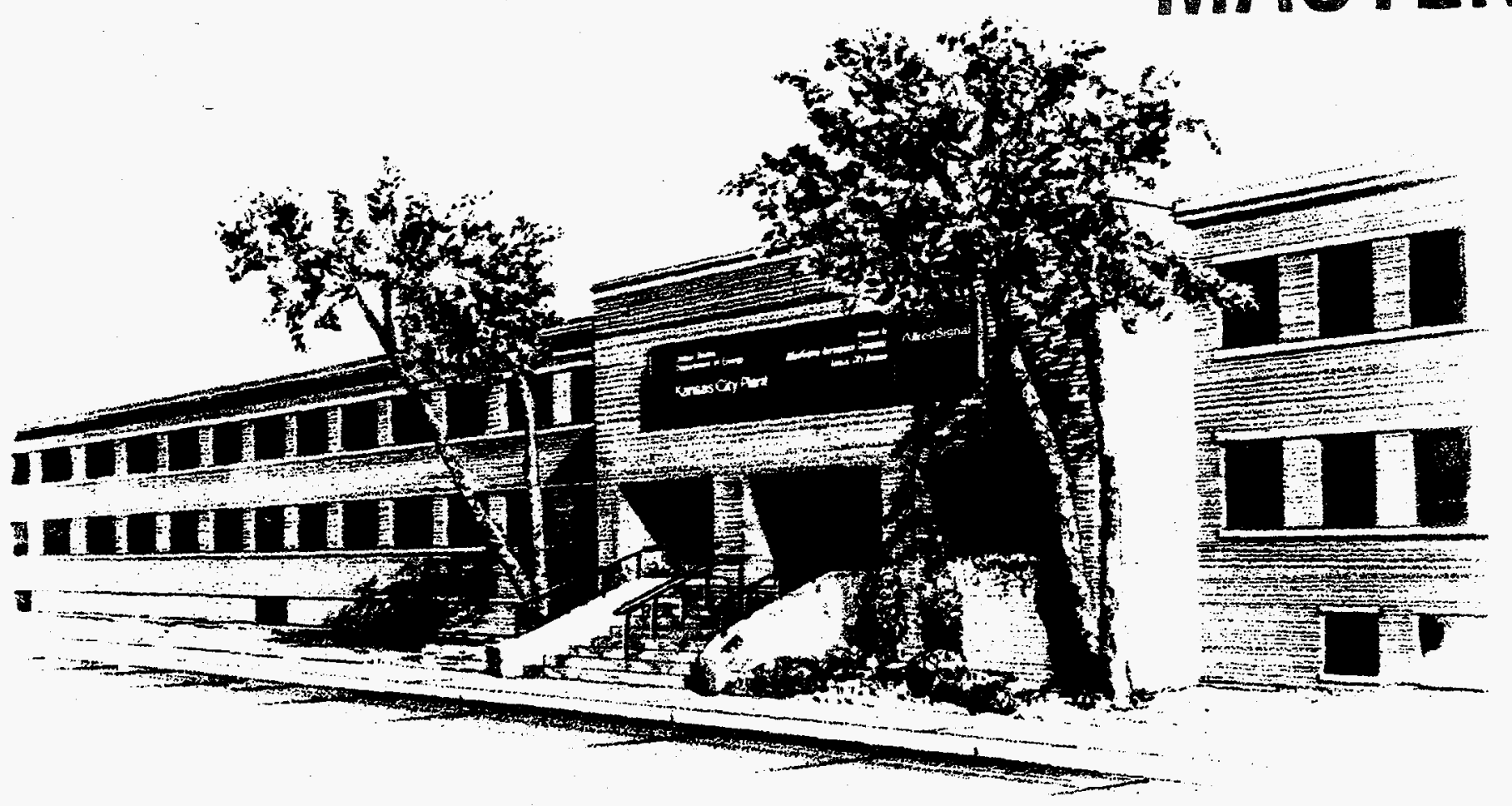




\section{DISCLAIMER}

This report was prepared as an account of work sponsored by an agency of the United States Government. Neither the United States Government nor any agency thereof, nor any of their employees, makes any warranty, express or implied, or assumes any legal liability or responsibility for the accuracy, completeness, or usefulness of any information, apparatus, product, or process

disclosed, or represents that its use would not infringe privately owned rights. Reference herein to any specific commercial product, process, or service by trade names, trademark, manufacturer, or otherwise, does not necessarily constitute or imply its endorsement, recommendation, or favoring by the United States Government or any agency thereof. The views and opinions of authors expressed herein do not necessarily state or reflect those of the United States Government or any agency thereof.

All data prepared, analyzed and presented has been developed in a specific context of work and was prepared for internal evaluation and use pursuant to that work authorized under the referenced contract. Reference herein to any specific commercial product, process or service by trade name, trademark, manufacturer, or otherwise, does not necessarily constitute or imply its endorsement, recommendation, or favoring by the United States Government, any agency thereof or AlliedSignal Inc.

Printed in the United States of America.

This report has been reproduced from the best available copy.

Available to DOE and DOE contractors from the Office of Scientific and Technical Information, P. O. Box 62, Oak Ridge, Tennessee 37831 ; prices available from (615) $576-8401$, FTS 626-8401.

Available to the public from the National Technical Information Service, U. S. Department of Commerce, 5285 Port Royal Rd., Springfield, Virginia 22161.

A prime contractor with the United States Department of Energy under Contract Number DE-ACO4-76-DP00613.
AlliedSignal Inc. Federal Manufacturing \& Technologies P. O. Box 419159 Kansas City, Missouri 64141-6159 


\section{DISCLAIMER}

This report was prepared as an account of work sponsored by an agency of the United States Government. Neither the United States Government nor any agency thereof, nor any of their employees, make any warranty, express or implied, or assumes any legal liability or responsibility for the accuracy, completeness, or usefulness of any information, apparatus, product, or process disclosed, or represents that its use would not infringe privately owned rights. Reference herein to any specific commercial product, process, or service by trade name, trademark, manufacturer, or otherwise does not necessarily constitute or imply its endorsement, recommendation, or favoring by the United States Government or any agency thereof. The views and opinions of authors expressed herein do not necessarily state or reflect those of the United States Government or any agency thereof. 


\section{DISCLAMMIRR}

Portions of this document may be illegible in electronic image products. Images are produced from the best available original document. 
KCP-613-5926

Distribution Category UC-706

Approved for public release; distribution is unlimited.

\title{
ALKALINE CLEANER REPLACEMENT FOR PRINTED WIRING BOARD FABRICATION
}

\author{
S. E. Goldammer, \\ S. E. Pemberton, and \\ D. R. Tucker
}

Published April 1997

Topical Report

Project Team:

C. W. Boehning

S. E. Goldammer

W. I. Highland

R. R. Hyder

D. E. Laughlin

T. A. Livengood

S. E. Pemberton

D. R. Tucker

D. E. Williams 


\section{Contents}

Section

Page

Abstract

1

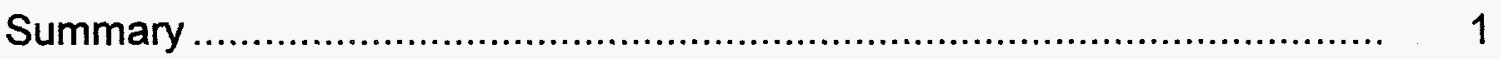

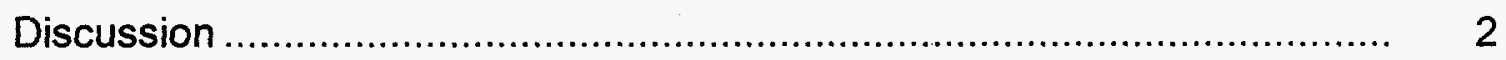

Scope and Purpose ................................................................... 2

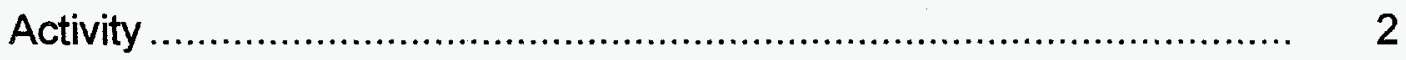

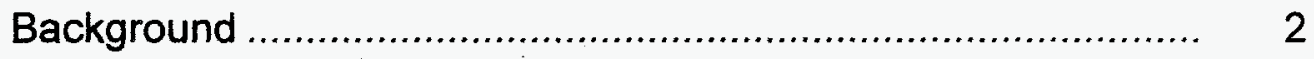

Preliminary Investigation .......................................................

Production Process Evaluation................................................. 4

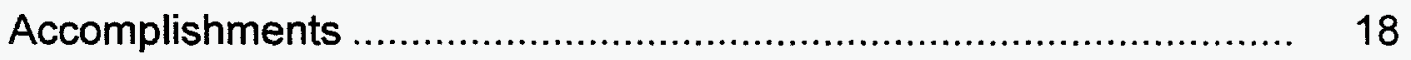

Appendices

A. Alkaline Cleaning Process ......................................................... 19

B. Cleaner Summary.............................................................. 21

C. Scanning Auger ................................................................. 24

D. Surface Analysis ................................................................ 26

E. Tabulated Data................................................................. 28 


\section{Illustrations}

Figure

Page

1 Chemical Clean Process Flow Chart................................................ 2

2 Copper Surface, No Cleaning ........................................................ 6

3 Copper Surface, CoSpray Cleaned ……………….......................... 7

4 Copper Surface, Metex Cleaned .................................................... 9

5 Uncleaned Copper................................................................... 10

6 CoSpray-Cleaned Copper ....................................................... 11

$7 \quad$ Metex-Cleaned Copper ........................................................... 11

8 Copper Surfaces With Plated Brown Oxide ................................... 12

9 Microscopic Photographs of Non-Brown Oxide Area ...................... 14

10 Photoresist Adhesion .............................................................. 15

11 Artwork Used for Photoresist Pattern Integrity ................................... 16

12 Weight Loss at 40 Inches per Minute, CoSpray ............................. 16

13 Weight Loss at Variable Cleaning Times, CoSpray Cleaned ............ 17

14 Weight Loss at Variable Cleaning Times, Metex Cleaned, Day $1 \ldots \ldots .17$

15 Weight Loss at Variable Cleaning Times, Metex Cleaned, Day $2 \ldots \ldots . .18$

\section{Tables}

Number

1 Ingredient Comparison of Metex-507 and CoSpray $1028 \ldots \ldots \ldots \ldots \ldots \ldots . . . . . . .3$

2 Photoresist Adhesion Test Results................................................ 4

3 Water Break Time Before and After Alkaline Cleaning ..................... 4 


\begin{abstract}
A replacement alkaline cleaning chemistry was qualified for the copper cleaning process used to support printed wiring board fabrication. The copper cleaning process was used to prepare copper surfaces for enhancing the adhesion of dry film photopolymers (photoresists and solder masks) and acrylic adhesives. The alkaline chemistry was used to remove organic contaminates such as fingerprints.
\end{abstract}

\title{
Summary
}

An alkaline cleaning chemistry, CoSpray 1028, manufactured by MacDermid, Incorporated, was evaluated and qualified for use in a cleaning process in printed circuit board manufacturing. This new chemistry replaced the existing alkaline chemistry, MacDermid's Metex P-507. CoSpray 1028 was compared to the Metex P-507 and found to be a "drop-in" replacement in the cleaning process which cleaned and prepared surfaces for improving the adhesion of

- photopolymer films (dry film photoresists, DuPont's Riston 9015, 4615, and 4620, and solder mask, DuPont's Vacrel 8140) to copper and

- adhesives (acrylic, DuPont's Pyralux) used to bond coverlay materials to flexible circuits. 


\section{Discussion}

\section{Scope and Purpose}

This evaluation was done to qualify a replacement alkaline cleaning chemistry to remove organic contaminates from copper surfaces during a cleaning process used in printed wiring board fabrication.

\section{Activity}

\section{Background}

Metex-P507, a proprietary alkaline cleaner used in a cleaning process during printed wiring board (PWB) fabrication, was going to be discontinued by the manufacturer, MacDermid, Incorporated. The manufacturer recommended an alternative alkaline chemistry, CoSpray 1028.

The chemical cleaning process (see Figure 1) was designed to prepare the copper clad panels in two ways. First, an alkaline cleaner was used to remove organic contaminates such as fingerprints and oils. Second, a solution of sodium persulfate, sulfuric acid, and deionized (DI) water was used to "microetch" the copper surface to remove the conversion coating (applied at the laminate manufacturers' facility) and copper oxides and to roughen the copper surface to improve adhesion of materials in subsequent processes such as

- photopolymer films (dry film photoresists, DuPont's Riston 9015, 4615, and 4620, and solder mask, DuPont's Vacrel 8140) to copper and

- adhesives (acrylic, DuPont's Pyralux) used to bond coverlay materials to flexible circuits.

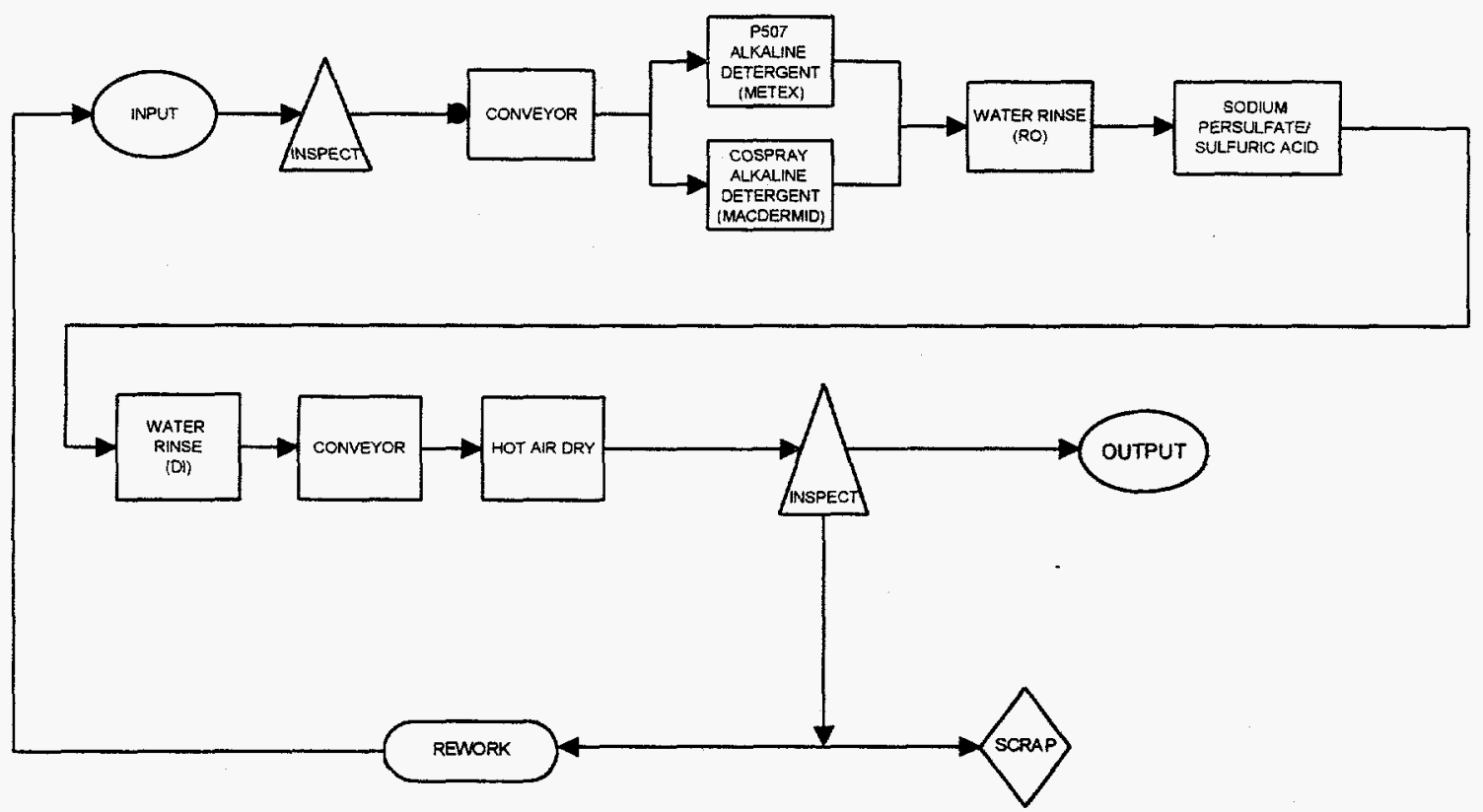

Figure 1. Chemical Clean Process Flow Chart 
An engineering release (ER) was written in February 1996 to document the need for an alternative cleaning chemistry.

\section{Preliminary Investigation}

Appendix A shows the entire cleaning process including the chemistries used, cleaning sequence, and operating parameters. A comparison of the ingredients of the Metex -P507 and CoSpray 1028 is shown in Table 1.

Table 1. Ingredient Comparison of Metex-P507 and CoSpray 1028

\begin{tabular}{lcc}
\hline INGREDIENT & METEX-P507 & COSPRAY 1028 \\
\hline Sodium Metasilicate & $50 \%$ & $12-15 \%$ \\
Trisodium Phosphate & $30 \%$ & \\
\hline
\end{tabular}

An initial laboratory-scale study was done to compare the two cleaning chemistries. Copper clad panels were cleaned in beakers filled with heated alkaline cleaners. After cleaning, the following responses were used to evaluate results of the two cleaners.

Brown oxide - The copper clad samples were coated with a brown oxide to provide a visual response of contaminant removal. The contaminant of interest was the conversion coating applied to circuit board laminate by the laminate manufacturers to reduce oxide formation on the copper. Brown oxide appearance generally was a uniform color on each panel, but the color could range from a golden brown to a dark brown from batch to batch. Copper samples that did not receive any cleaning indicated that the brown oxide bath could not remove the conversion coatings-brown oxide would not form.

The samples cleaned in only the alkaline chemistries (15-minute soak at $140^{\circ} \mathrm{F}$ ) and processed through brown oxide appeared to be similar. Neither cleaner was able to produce a normal brown oxide appearance after immediate immersion into the brown oxide bath. In contrast, copper panels which were cleaned in the microetch chemistry, regardless whether they had first been cleaned with Metex P-507, CoSpray 1028, or microetch only (no alkaline cleaning at all), had a golden brown oxide surface following immediate immersion into the brown oxide chemistry. The microetch, not the alkaline cleaner, proved to be the critical contributor for successful brown oxide coating.

Adhesion test - Dry film photoresist was laminated on the pre-cleaned copper and stainless steel surfaces. (Stainless steel was used for chemically machined parts.) A qualitative test of the adhesion of the photoresist to the copper and stainless steel was measured using ASTM 3359-87, Method B.

DuPont's 4615 dry film photoresist was laminated onto the copper and stainless steel substrates which were cleaned in Metex P-507 and CoSpray 1028. Using the tool provided with the ASTM test kit, a set of parallel lines was scribed through the photoresist, and another set of parallel lines was scribed through the photoresist perpendicular to the first set of parallel lines. Pressure-sensitive tape was secured to the intersection of the two sets of lines and removed. The amount of resist that was removed with the tape was the response and was ranked from 0 to 5 . If the tape did not remove resist, the ranking was 5 . If all the resist was removed, the ranking was a 0 . 
The results are shown in Table 2.

Table 2. Photoresist Adhesion Test Results

\begin{tabular}{lcc}
\hline CHEMISTRY & ADHESION TEST - & ADHESION TEST - \\
& Stainless Steel & Copper \\
MetexP 507 & 2.9 & 4.1 \\
CoSpray 1028 & 1.9 & 4.2 \\
\hline
\end{tabular}

Water break test - A simple test was performed by observing how a coating of clean water responded to the chemically cleaned copper substrates. Substrates were immersed in clean water and removed. The water film was observed over a period of time for separation and breaking. A quick separation or "break" in the water film indicated the presence of contamination in the area of separation. A slow and even evaporation or drying of the water film on the entire panel indicated that the copper was relatively clean. Water breaking was timed before and after cleaning in either Metex P-507 or CoSpray 1028. A slight improvement in water break time was noticed following the alkaline cleaning. The results are shown in Table 3.

Table 3. Water Break Time Before and After Alkaline Cleaning

\begin{tabular}{|cc}
\hline CONDITION OF COPPER & $\begin{array}{c}\text { BREAK TIME } \\
\text { (SECONDS) }\end{array}$ \\
Prior to Metex P -507 & 10 \\
After Wetex P $\mathbf{5 0 7}$ & 24 \\
Prior to CoSpray 1028 & 6.5 \\
After CoSpray 1028 & 31 \\
\hline
\end{tabular}

These results were documented (see Appendix B) and presented to the Qualification Evaluation Team, a team of associates from Sandia National Laboratories and AlliedSignal Federal Manufacturing \& Technologies/Kansas City (FM\&T/KC). The team agreed that the CoSpray 1028 should be evaluated in a production cleaning system.

\section{Production Process Evaluation}

The preliminary work discussed above showed that the CoSpray 1028 would be a potential replacement for the Metex P-507. The next step was to compare the CoSpray 1028 to the Metex P-507 in the actual cleaning equipment in the production department.

The alkaline cleaning chemistry was designed to remove organic contaminants, and the microetch chemistry was designed to remove the conversion coating (once the organics were removed) and roughen the copper surface to enhance adhesion in subsequent processes. This study explored the ability of both cleaners to remove a variety of contaminants that could potentially be found on production panels. Potential contaminants included fingerprints, adhesive residue from labels, and unknown contaminants from things such as prolonged storage or supplier surface treatments. 
Three categories of copper clad panels were found in storage. Some had no discoloration. These were relatively new panels in which the conversion coating was still inhibiting oxide growth. Some panels had a full covering of a dark brown oxide, and the remaining panels had some oxide areas and some clear areas. These had been in storage for several years.

Perhaps a conversion coating had not been applied or, if so, had degraded with time. It could have been that a different contaminant was masking either the clear or oxide areas. Whatever the case, the cleaning process needed to be robust enough to remove the different oxides found on incoming materials.

The three groups of copper surfaces used during this evaluation were the following.

1. Clear - copper panels with no discoloration. These were labeled "clear."

2. Oxide - copper panels with a heavy natural oxide coating (formed in storage) which ranged in appearance from dark brown to dark red.

3. Mixed - copper panels with some oxide areas and some clear areas.

Photographs from scanning electron microscopy (SEM) at 1000X magnification of the clear and oxide copper surfaces before any cleaning are shown in Figures $2 a$ and $2 b$.

The surface topography of the copper surface with natural oxide is much more coarse than the surface topography of the clear copper finish, indicating a difference in the incoming copper surfaces.

Copper surfaces were processed in one of the four following ways:

1. CoSpray low - panels cleaned with CoSpray at the assumed worst-case condition of low CoSpray concentration ( 8.0 grams per liter) and low operating temperature (109 Fahrenheit).

2. CoSpray high - panels cleaned with CoSpray at the assumed best-case condition of high CoSpray concentration (24.0 grams per liter) and high operating temperature (140 Fahrenheit).

3. Metex P-507 - Panels were cleaned with Metex P-507 for baseline.

4. No clean - Some panels were not cleaned at all.

Figures $3 a$ through $3 c$ show photographs of SEMs at $1000 \times$ magnification from both the clear and oxide panels after cleaning in CoSpray 1028 and Metex P-507. 

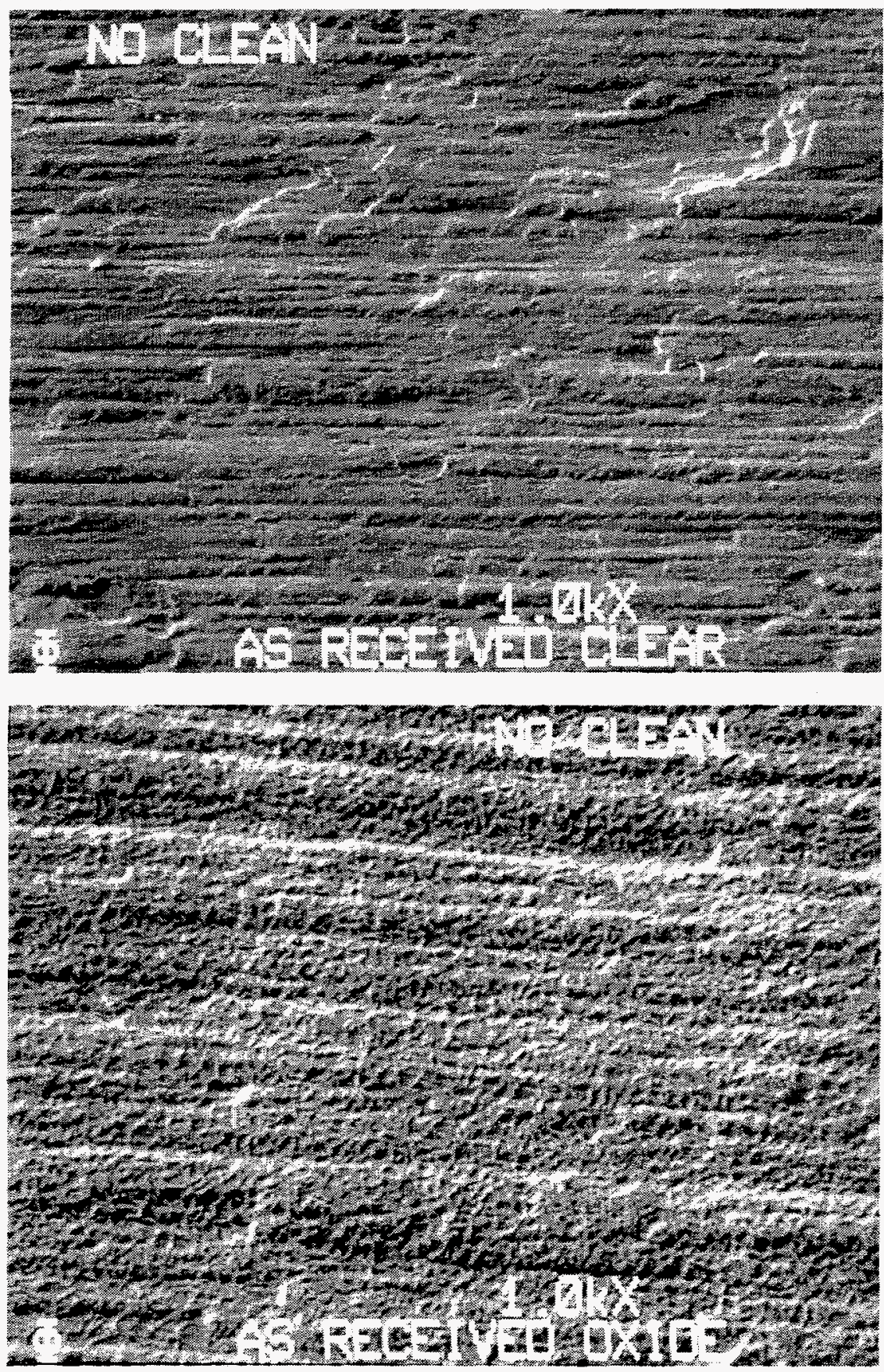

a. SEM OF CLEAR COPPER SURFACE AT $1000 \mathrm{X}$

\section{b. SEM OF OXIDE COPPER SURFACE AT $1000 \mathrm{X}$}

Figure 2. Copper Surface, No Cleaning 

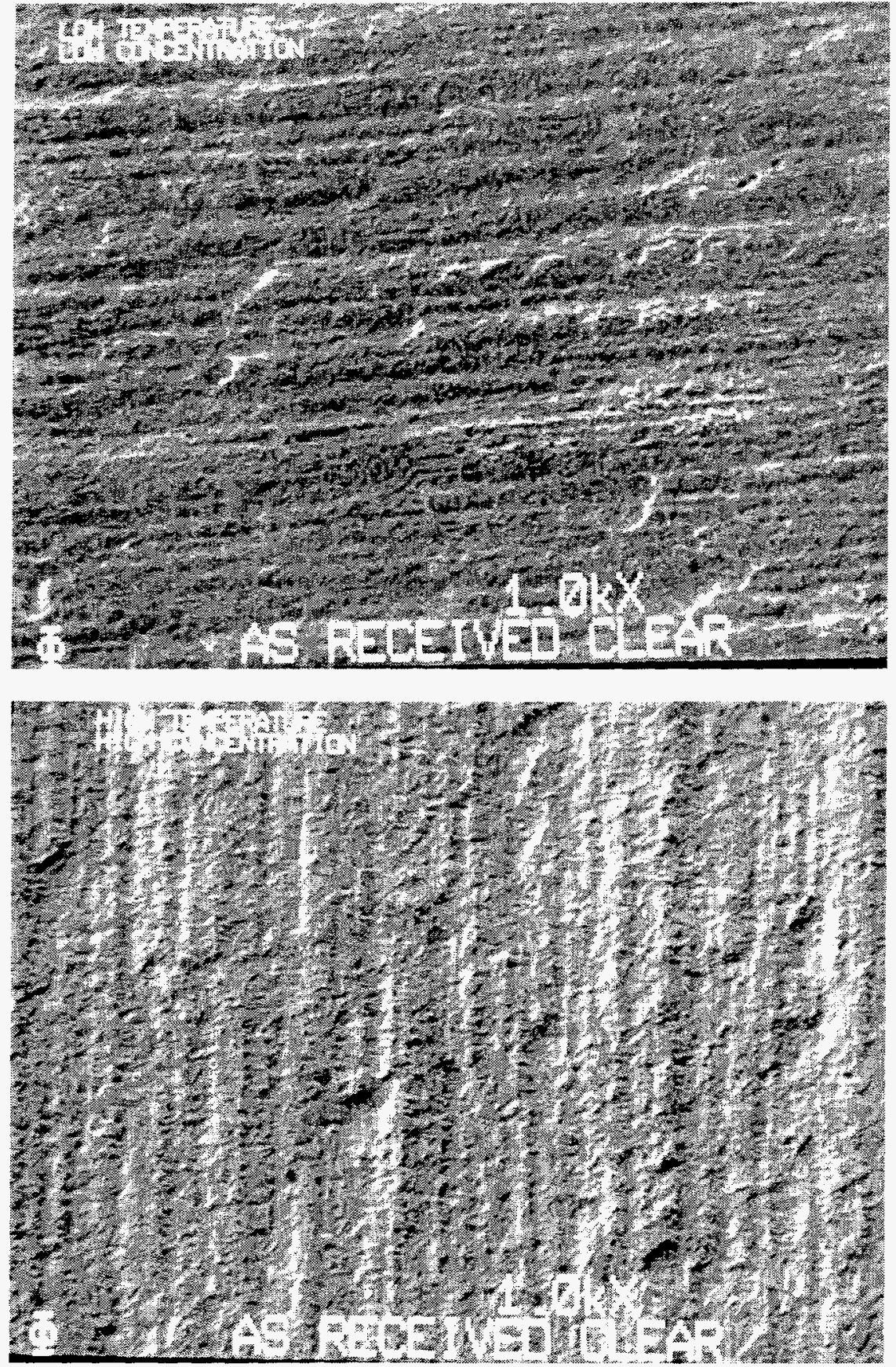

Figure 3. Copper Surface, CoSpray Cleaned a. CLEAR COPPER, COSPRAYCLEANED WITH LOW-SOLUTION TEMPERATURE AND CONCENTRATION

b. CLEAR COPPER, COSPRAYCLEANED WITH HIGH-SOLUTION TEMPERATURE AND CONCENTRATION 

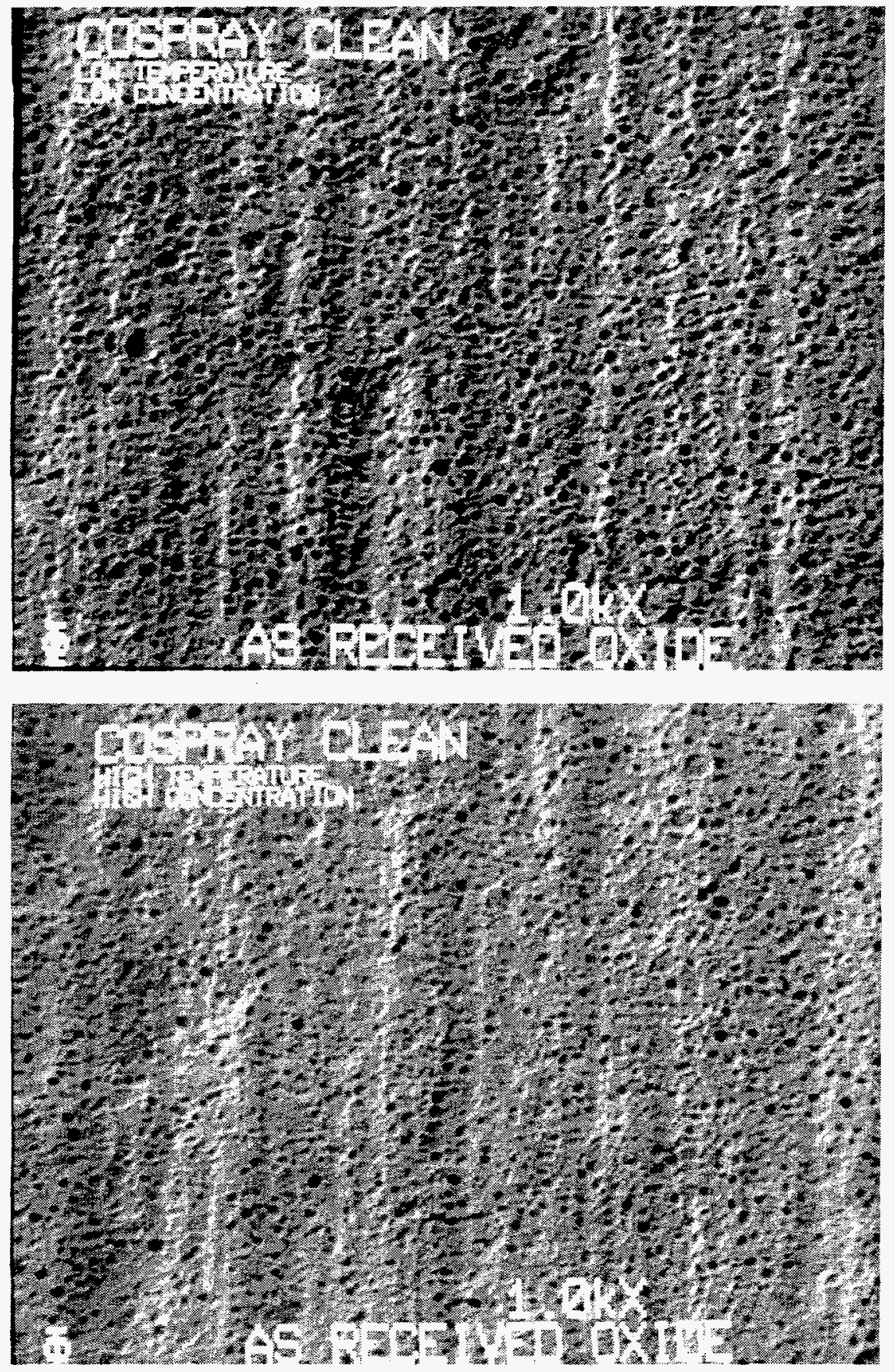

C. OXIDE COPPER, COSPRAYCLEANED WITH LOW-SOLUTION TEMPERATURE AND CONCENTRATION

Figure 3 continued. Copper Surface, CoSpray Cleaned

A comparison of the surface appearance of Figures $3 a$ and $3 b$ shows that the difference in CoSpray 1028 chemistry parameters can not be distinguished. Panels cleaned with low solution temperature and concentration looked the same as panels cleaned with high solution temperature and concentration. The microetch which actually etches the copper has more impact on the copper surface topography during the cleaning process.

The same results are true in comparing Figures $3 c$ and $3 d$. Again, changing the alkaline chemistry parameter did not impact surface topography. 
Figure 4 shows the surfaces of panels cleaned in Metex P-507. After cleaning, a difference in the as-received clear panel and the as-received oxide-covered panel can be detected.

Regardless of the cleaner used, the general trend of surface topography was the same in the clear and oxide as-received panels, although the topography peaks and valleys are more distinctive in panels cleaned with the CoSpray 1028.
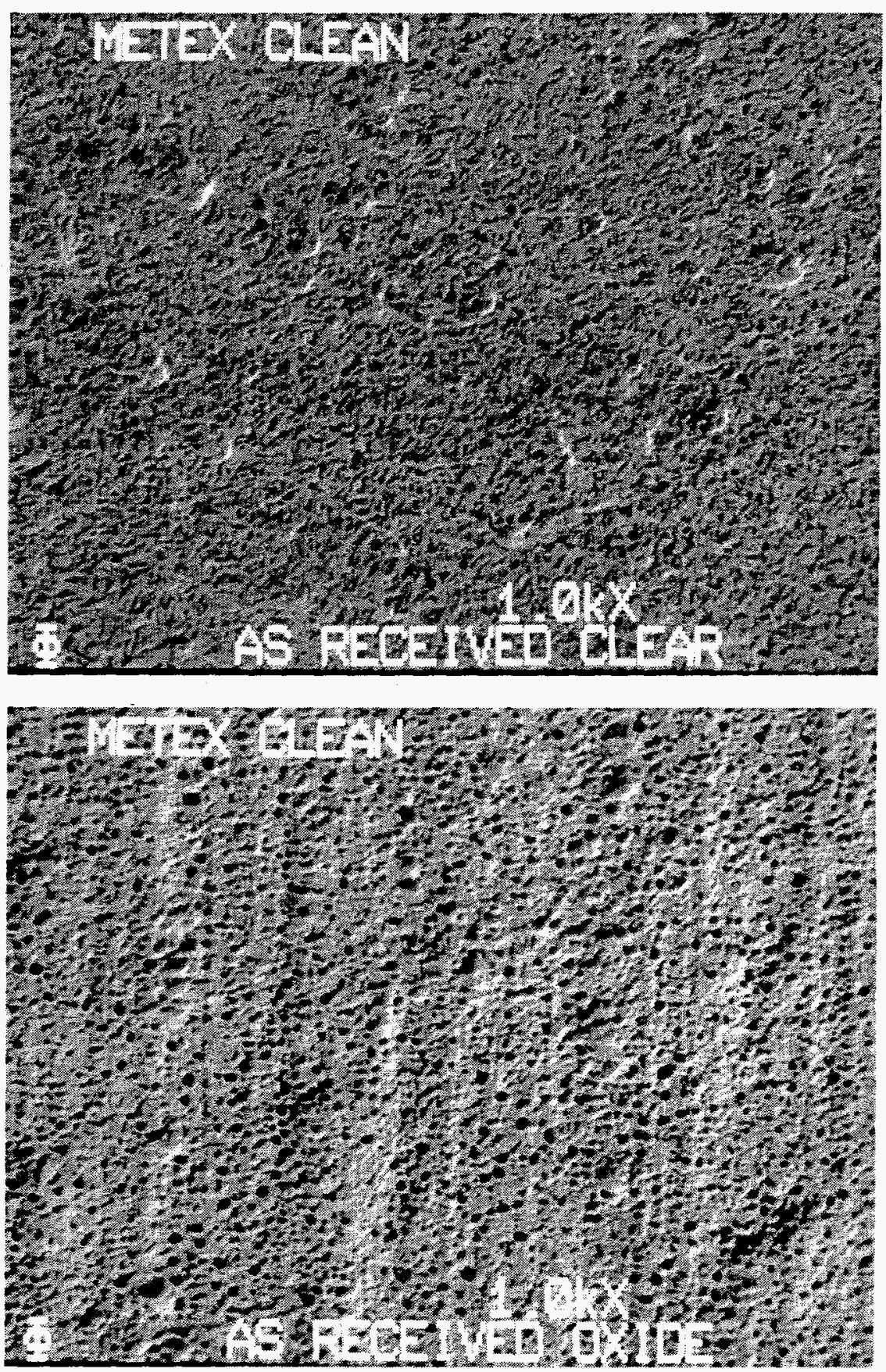

a. CLEAR COPPER, METEX CLEANED

\section{b. OXIDE COPPER, METEX CLEANED}

Figure 4. Copper Surface, Metex Cleaned 
Six responses were used to compare the two cleaning chemistries.

1. Organic contamination analysis - Scanning electron microscopy (SEM) and scanning auger microscopy (SAM) were used to detect residual contaminates on both the front and back side of three panels from each group. Copper, oxygen, chlorine, and carbon were detected on the specimens from panels cleaned in Metex P-507 and CoSpray 1028 and specimens from panels that were not cleaned. Chrome and zinc (as-received vendor coating) were additional elements detected on the samples that were not cleaned.

A discussion of the SAM and SEM technologies is provided in Appendix C.

Figures 5,6 , and 7 show the relative amounts of contaminants detected on each product type. The spreadsheet data of copper surface analysis is shown in Appendix D.

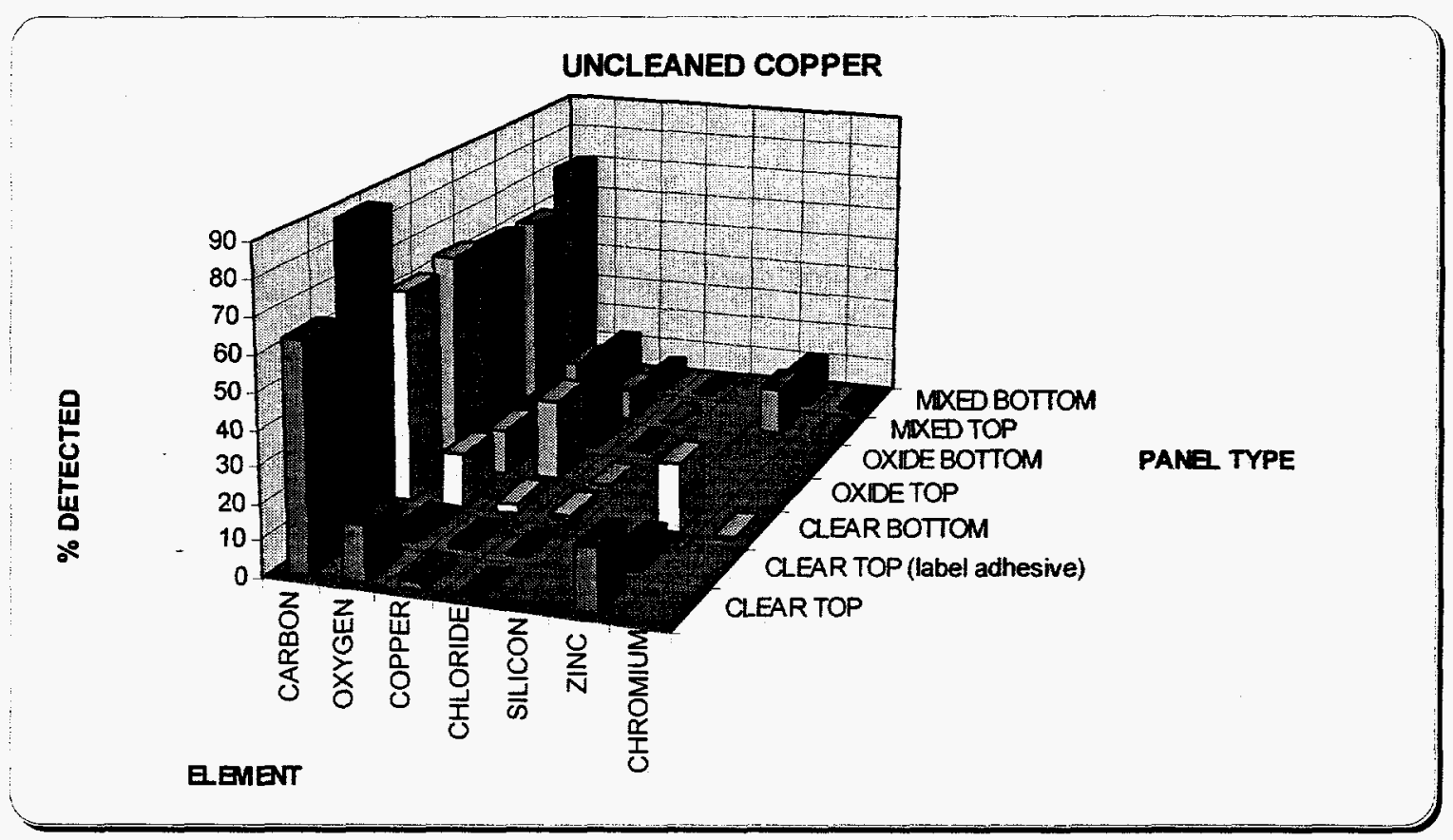

Figure 5. Uncleaned Copper

Figure 5 shows the as-received panel types, the elements detected on the surface of each, and the atomic concentrations of each element that were detected. Each as-received sample had some level of zinc and chromium but after cleaning, whether cleaned with the CoSpray 1028 (Figure 6) or the Metex P-507 (Figure 7), no zinc or chromium was detected. 


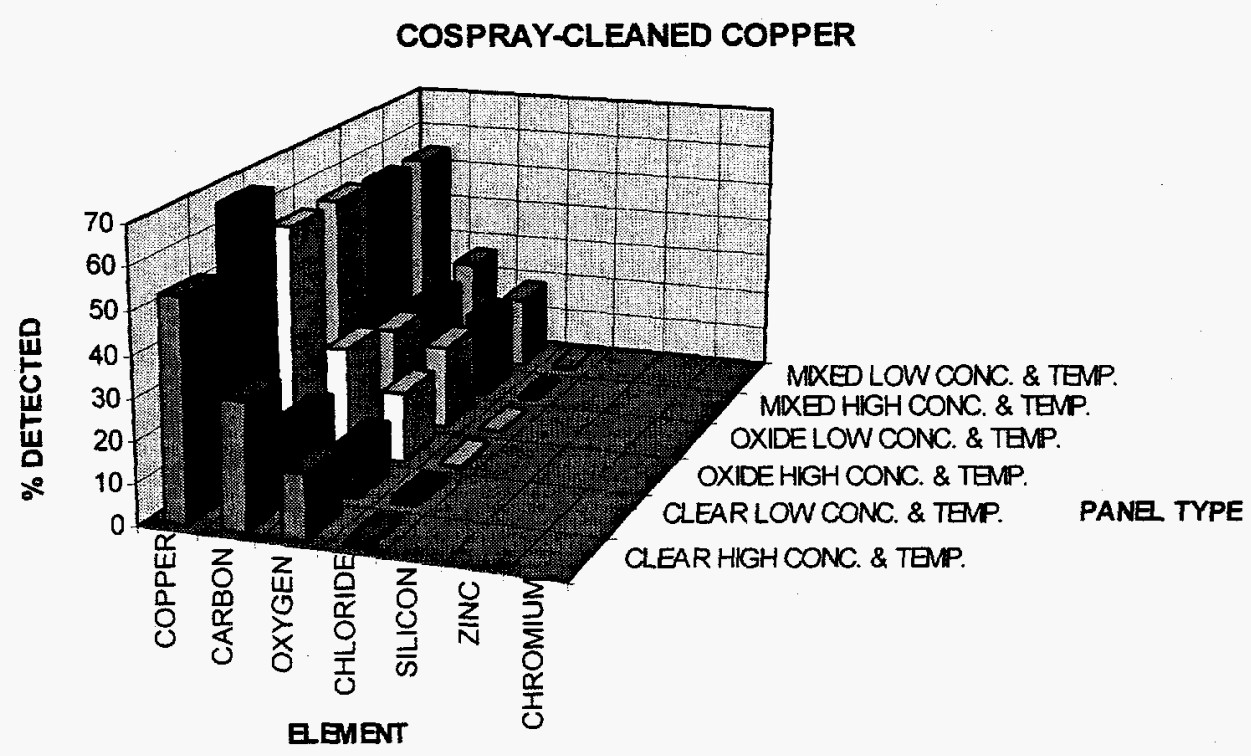

Figure 6 . CoSpray-Cleaned Copper

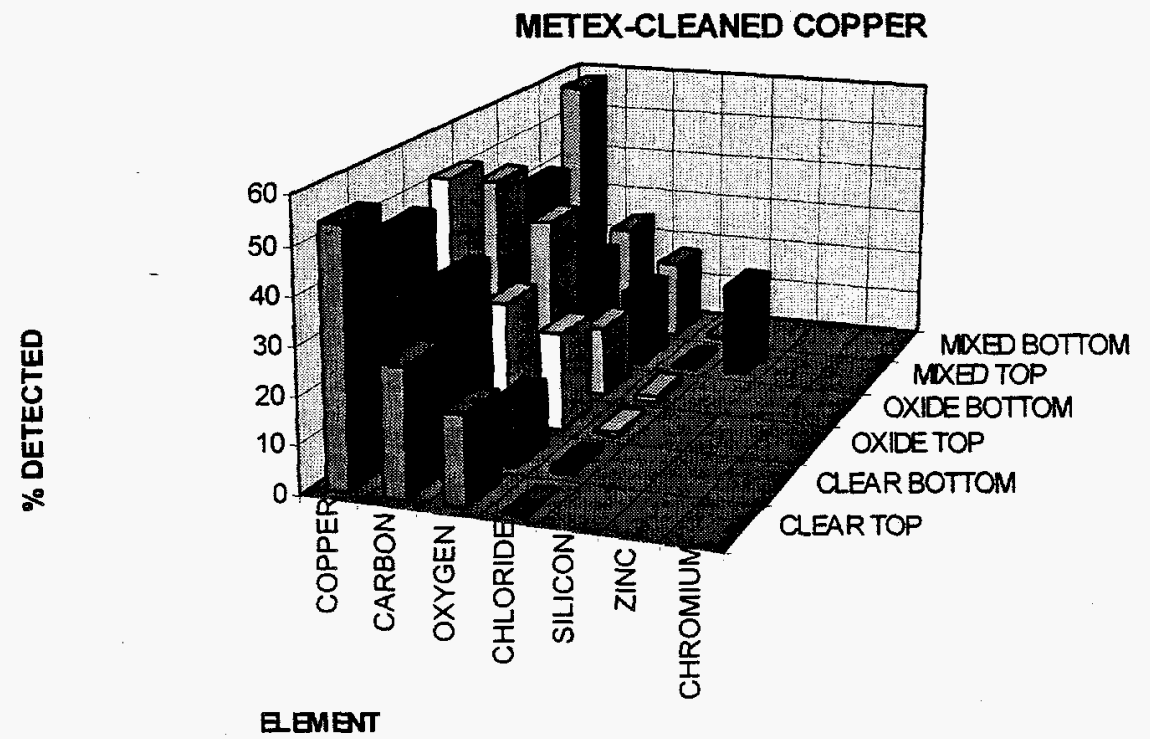

PANE TYPE

Figure 7. Metex-Cleaned Copper

2. Brown oxide - Three panels from each group were processed in plated brown oxide after cleaning. The plated brown oxide coating could not be distinguished from the panels cleaned in Metex P-507 and those cleaned in CoSpray 1028 and regardless of grouping (oxide, mixed, clear). The plated brown oxide coating was inferior in places where labels had been attached to the copper prior to cleaning. It appeared that neither the Metex P-507 nor the CoSpray 1028 was effective in removing label residue. Panels that were not cleaned, however, had almost no plated brown oxide coating (due to the as-received vendor coating). 
SEMs of the plated brown oxide coating on both Metex P-507-and CoSpray-cleaned panels are shown in Figures $8 \mathrm{a}$ through $8 \mathrm{c}$. Photographs are magnified $1000 \mathrm{X}$.
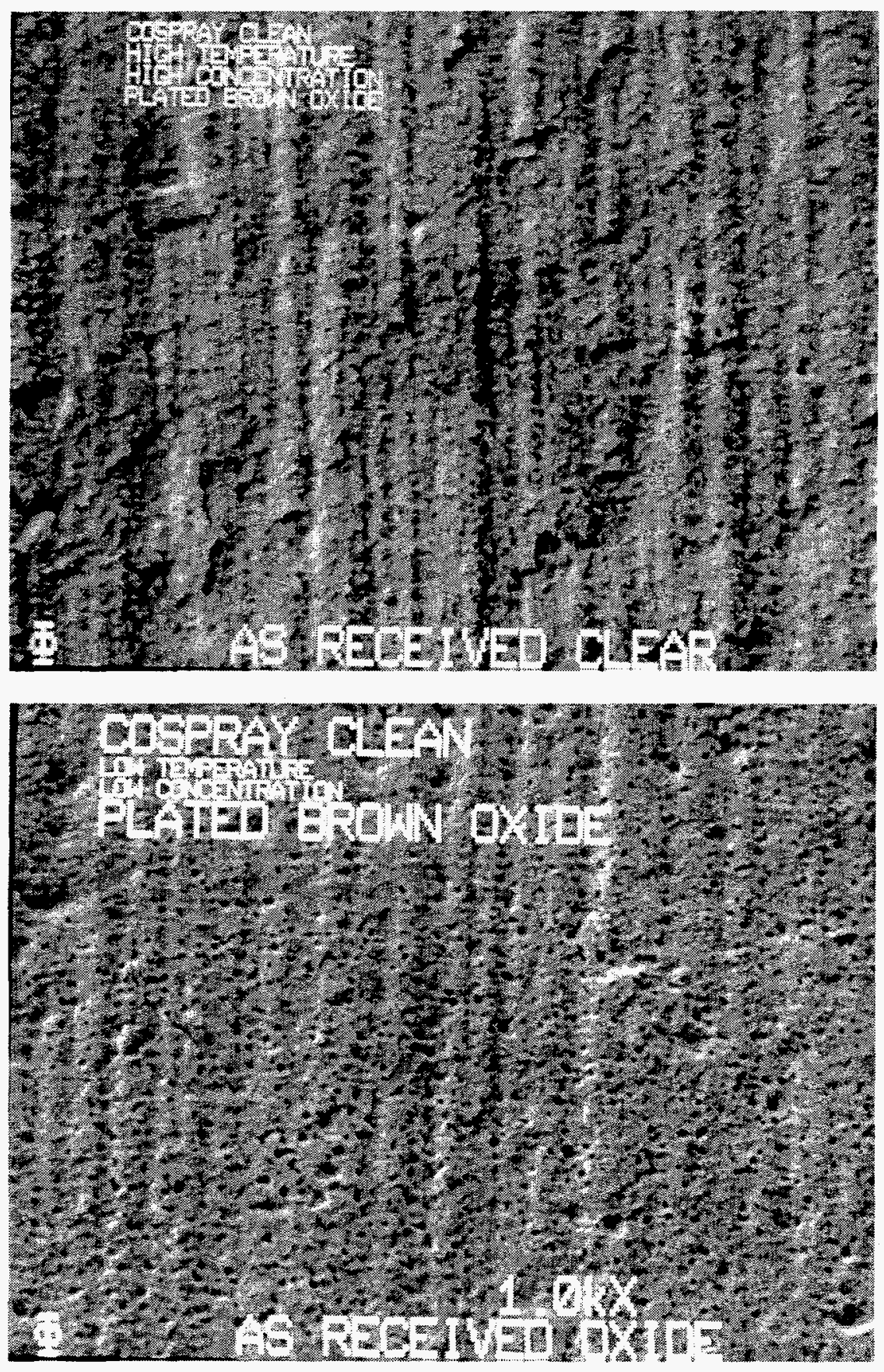

a. COSPRAY-CLEANED COPPER WITH PLATED BROWN OXIDE. (COPPER WAS CLEAR PRIOR TO CLEANING.)

Figure 8. Copper Surfaces With Plated Brown Oxide
b. COSPRAY-CLEANED COPPER WITH PLATED BROWN OXIDE. (COPPER HAD OXIDE COATING PRIOR TO CLEANING.)




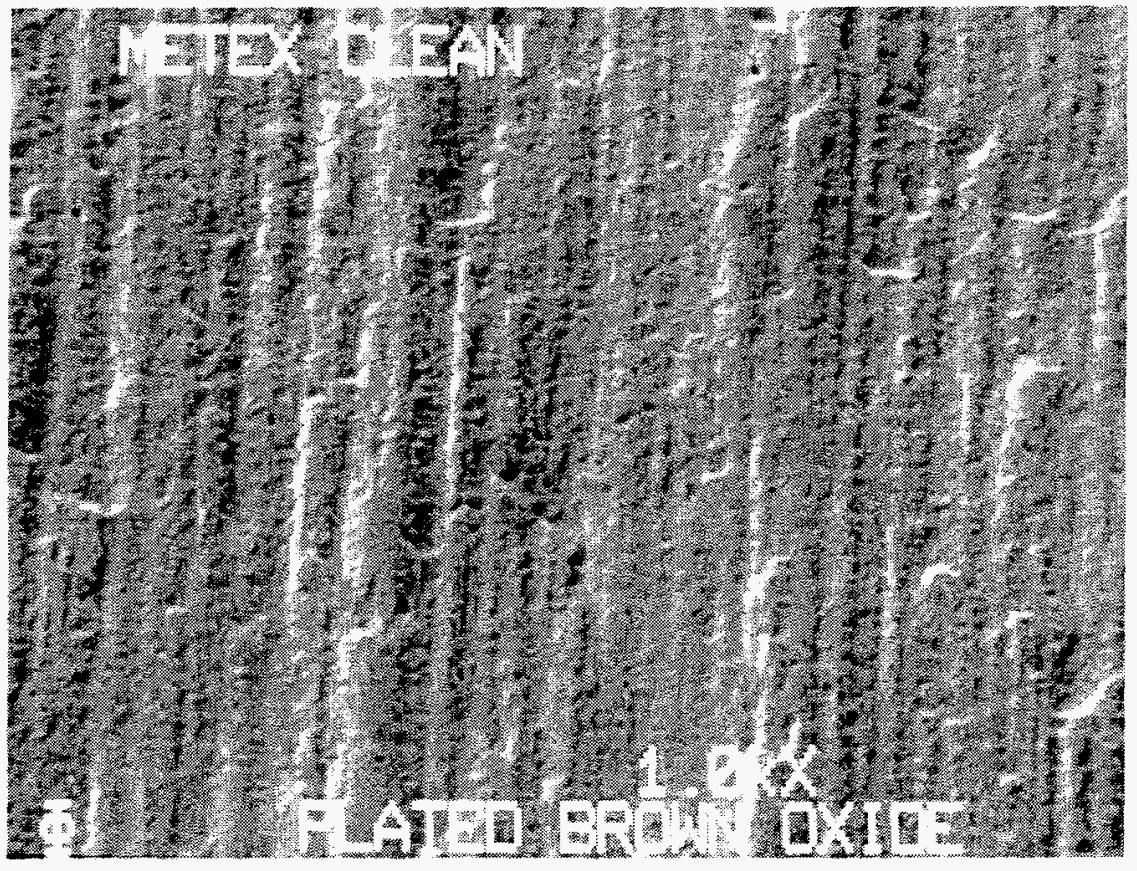

\section{c. METEX-CLEANED COPPER WITH PLATED BROWN OXIDE}

Figure 8 continued. Copper Surfaces With Plated Brown Oxide

In comparing Figures $8 \mathrm{a}, 8 \mathrm{~b}$, and $8 \mathrm{c}$, each surface can be matched to the original copper surface prior to cleaning. Figure $8 \mathrm{a}$, cleaned in CoSpray 1028, looks exactly like Figure 8c, cleaned in Metex P-507, showing that the difference in alkaline chemistries is not significant. Figure $8 \mathrm{~b}$, however, had the natural oxide coating prior to cleaning and does look different from Figures $8 \mathrm{a}$ and $8 \mathrm{c}$.

There were occasionally some small isolated areas on the plated brown oxide panels that did not have brown oxide coating. These areas were analyzed with SEM. The SEM photographs are shown in Figures $9 \mathrm{a}$ and $9 \mathrm{~b}$.

Results of the analysis of the non-brown oxide area are shown in Figure 10. Although the amounts of contamination are small, they did affect the appearance of the brown oxide coating. These slight variations in the coating were acceptable on production product.

3. Photoresist adhesion test - Three panels from each group were tested for photoresist adhesion. The results of the photoresist adhesion test for the panels cleaned in CoSpray 1028 are shown in Figure 10. Data for the charts is shown in Appendix $E$. The values agree with those done during the preliminary tests comparing Metex P-507 to CoSpray 1028 (see Table 2). 

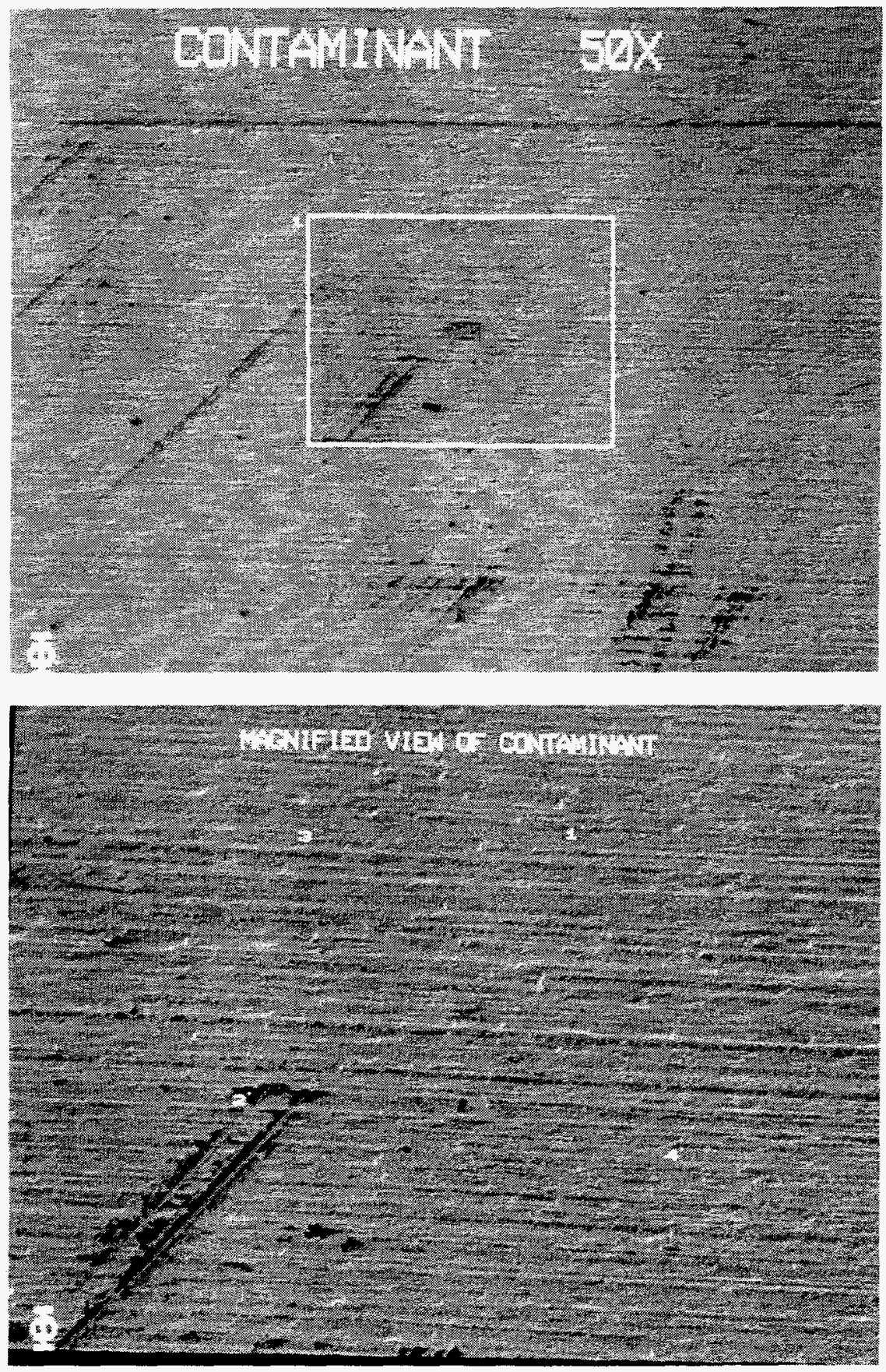

Figure 9. Microscopic Photographs of Non-Brown Oxide Area a. SEM OF A NON-BROWN OXIDE AREA AT 50X

\section{b. SEM OF A NON-BROWN OXIDE AREA AT GREATER THAN 5OX}




\section{PHOTORESIST ADHESION}

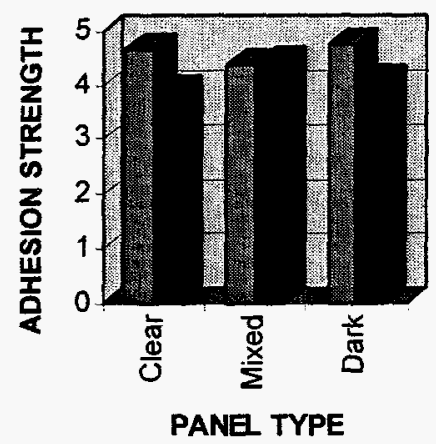

Low Concentration

Low Temperature'

High Concentration

High Temperature

PANE TYPE

Figure 10. Photoresist Adhesion

4. Water break test - Two panels from each group were used for the water break test. All groups of panels cleaned in CoSpray 1028 and Metex P-507 passed the water break test. The difference in water break test between the groups of panels, cleaning chemistry, and chemistry parameters was insignificant and similar to those values shown in the preliminary work (Table 3).

5. Quality of imaged photoresist - A pattern with a variety of feature shapes and sizes was used to image the opposite side of the panels that the peel test was performed on. The artwork used was a phototool (see Figure 11). The differences in the developed pattern were insignificant between the panels regardless of which group they were from and which cleaning chemistry and chemistry parameters to which they had been exposed.

Some photoresist patterns were poorly defined in small isolated areas that were probably covered with pressure-sensitive labels prior to cleaning. These areas appeared to be the same size as those not covered with brown oxide. Neither the Metex P-507 nor the CoSpray 1028 was effective in removing label residue. Although label residues are removed manually prior to chemical clean, the residues were left on the panels during this evaluation to determine if there was a difference in residue removal with one cleaner or another.

6. Weight loss - Figure 12 shows the amount of weight loss (in grams) of panels before and after cleaning in the CoSpray 1028. All panels were cleaned for the same amount of time. Weight loss was greater for the high solution concentration and temperature than for the low solution concentration and low temperature. 


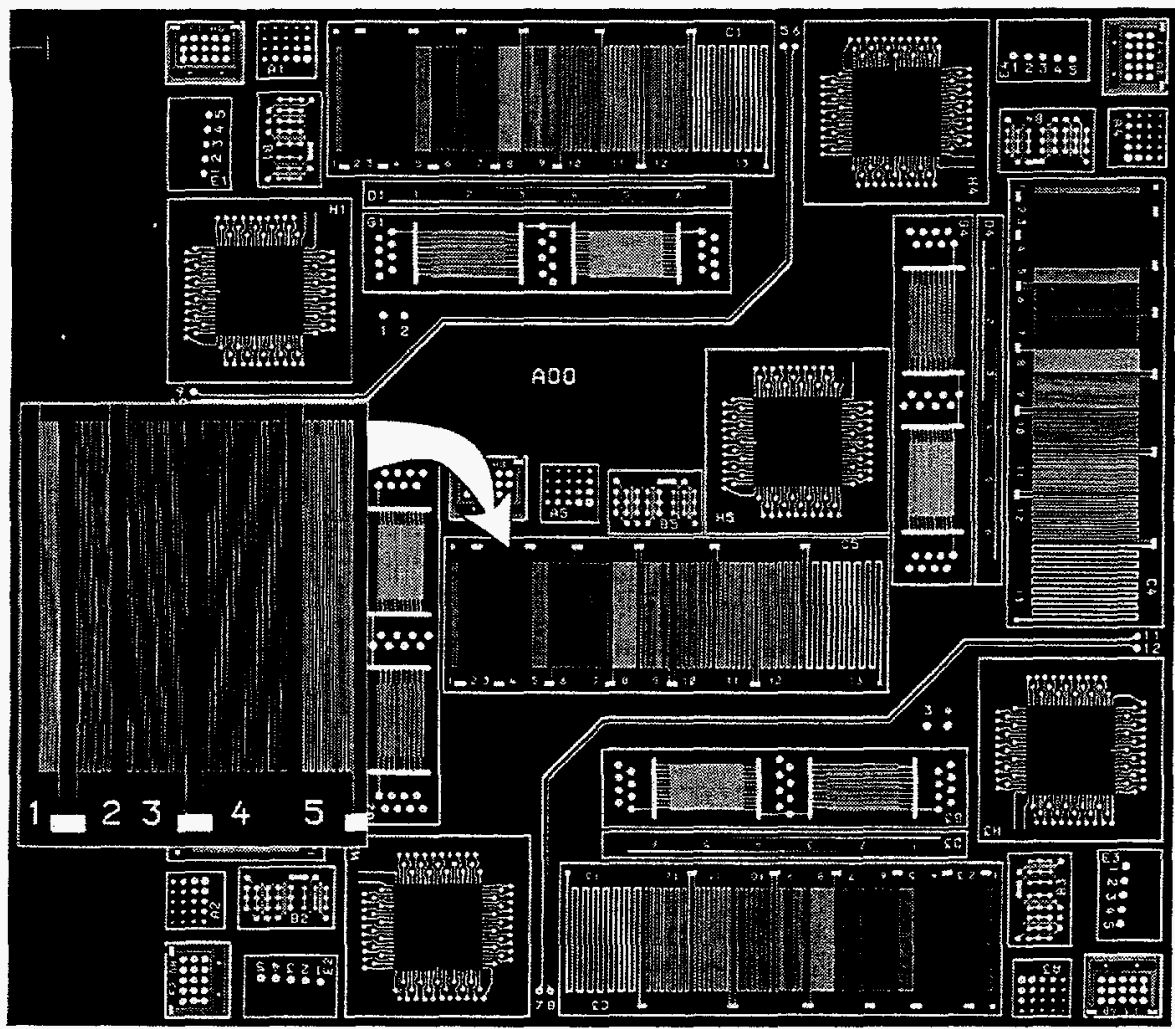

Figure 11. Artwork Used for Photoresist Pattern Integrity

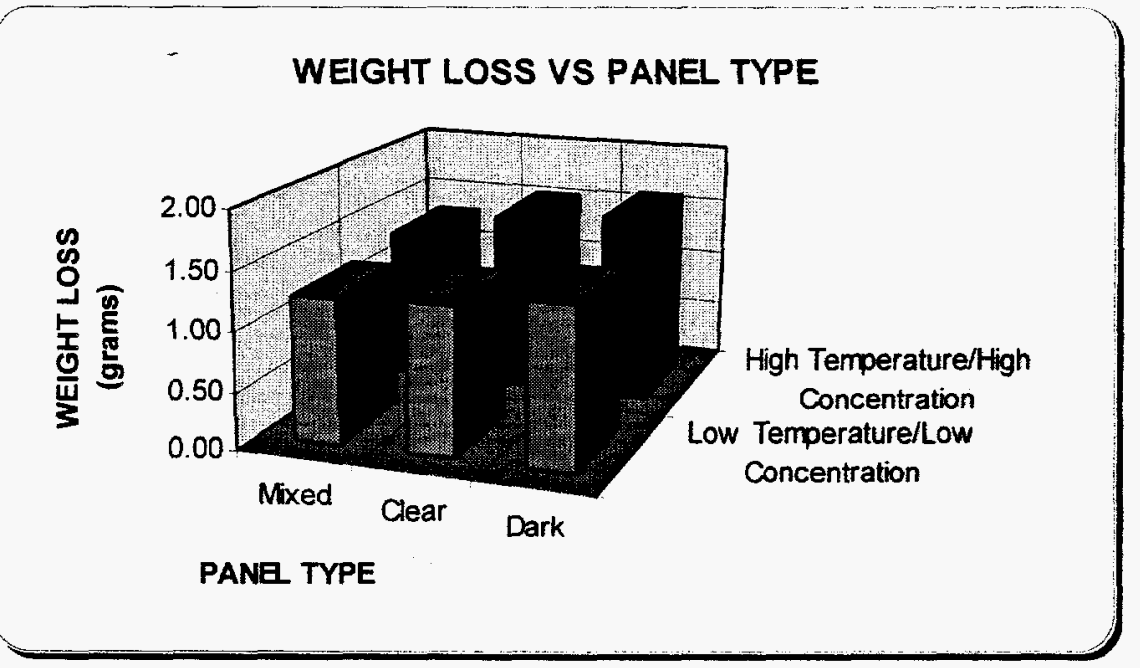

Figure 12. Weight Loss at 40 Inches per Minute, CoSpray

Figure 12 shows that weight loss was slightly affected by the solution temperature and concentration. Weight loss was greater using the higher-temperature, higher-concentration (more aggressive) cleaning solution. The data also shows a slight difference in weight loss between groups of panels. The data for Figure 12 is shown in Appendix $E$. 
Additional work was done to determine the impact of cleaning time (controlled by conveyor speed) on weight loss of the copper clad panels. Figure 13 shows the conveyor speed versus weight loss for the CoSpray 1028. Data for Figure 13 is shown in Appendix $E$. Weight loss was calculated for both the top and bottom side of the panels to determine if the top-to-bottom copper removal was uniform. Weight loss was greater for panels cleaned for longer times (the slower the conveyor speed, the longer the cleaning time). Again, the weight loss was greater for panels cleaned with a high-temperature, high-concentration cleaning solution.

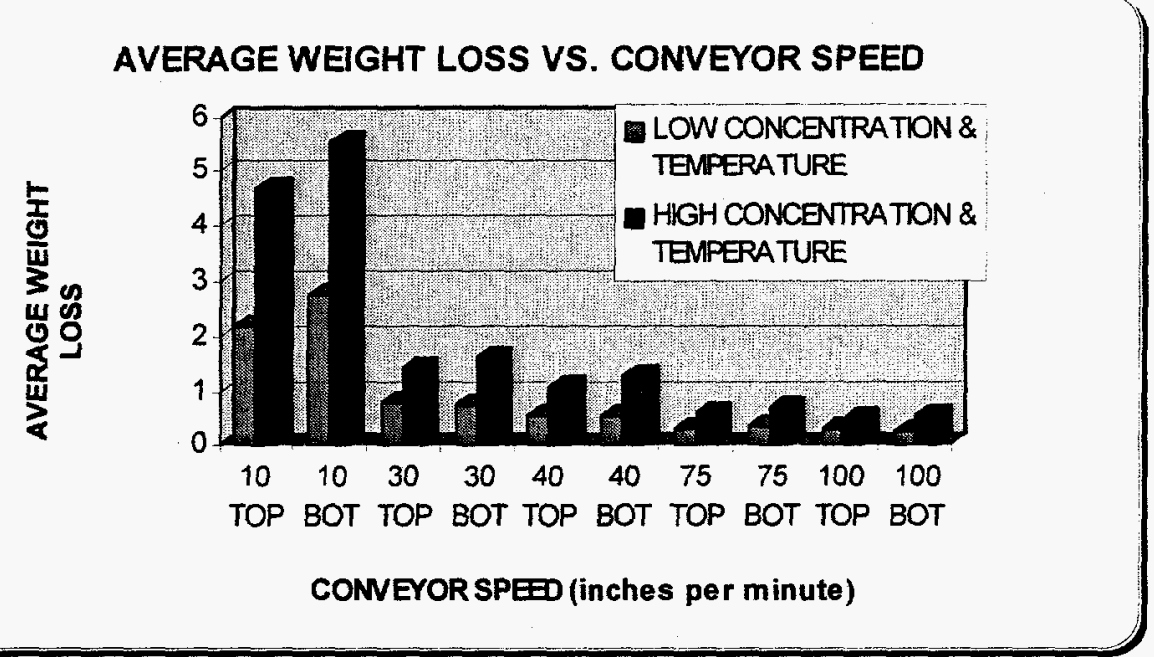

Figure 13. Weight Loss at Variable Cleaning Times, CoSpray Cleaned

Figures 14 and 15 show a similar study that was done with Metex P-507. Figures 13, 14, and 15 are similar in that as the conveyor speed is increased (cleaning time increased), the weight loss is decreased.

\section{CONVEYOR SPEED VS. WEIGHT LOSS}

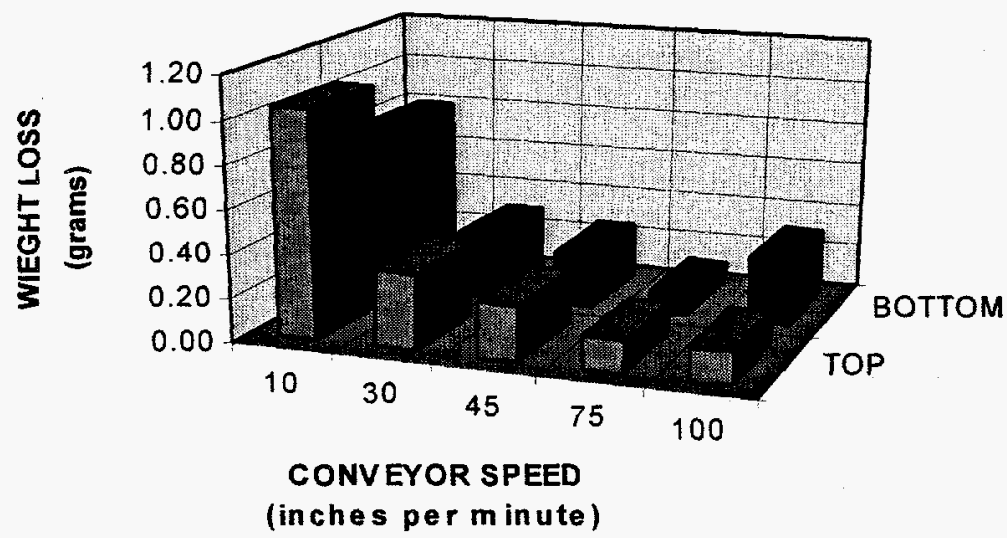

Figure 14. Weight Loss at Variable Cleaning Times, Metex Cleaned, Day 1 


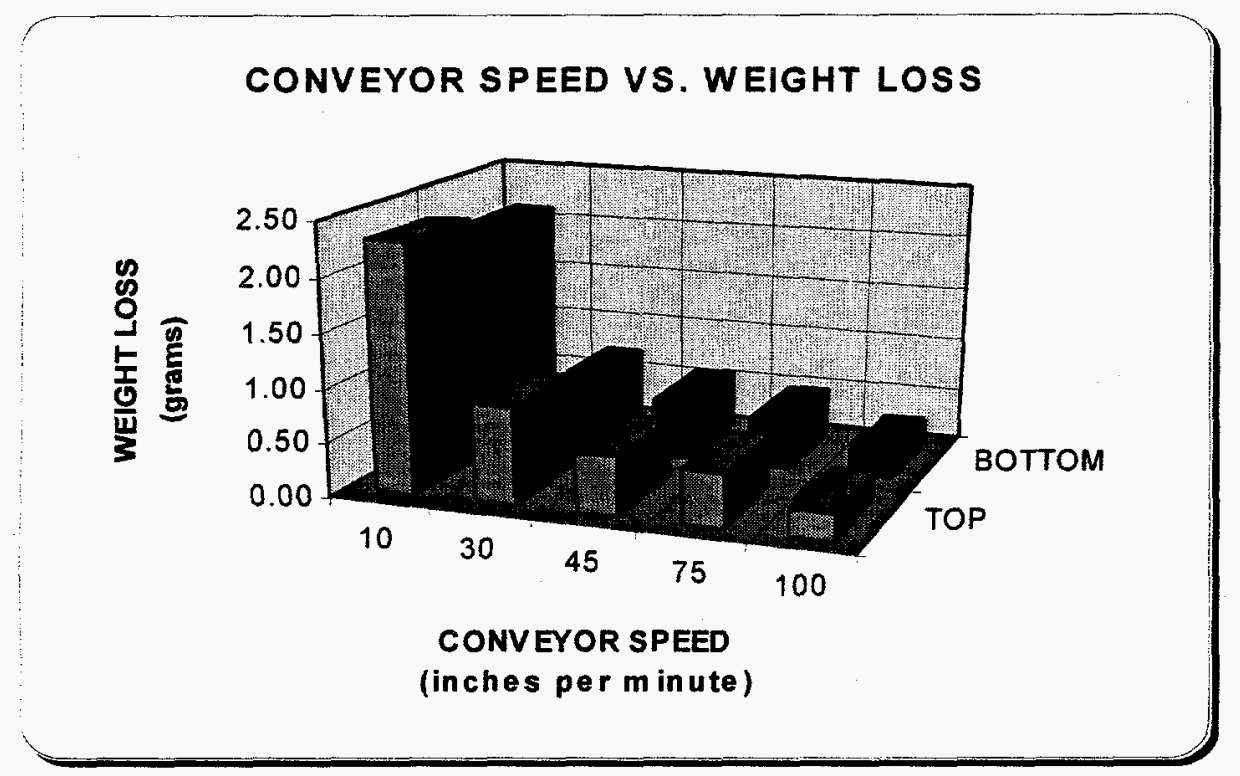

Figure 15. Weight Loss at Variable Cleaning Times, Metex Cleaned, Day 2

\section{Accomplishments}

The CoSpray 1028 was shown to be a "drop-in" replacement for the Metex P-507. The CoSpray 1028 performed as well as the Metex P-507 in cleaning and preparing surfaces for improving the adhesion of

- photopolymer films (dry film photoresists, DuPont's Riston 9015, 4615, and 4620, and solder mask, DuPont's Vacrel 8140) to copper, and

- adhesives (acrylic, DuPont's Pyralux) used to bond coverlay materials to flexible circuits.

Surface analysis of specimens from panels cleaned in Metex P-507 and CoSpray 1028 were similar. The surface texture of specimens from panels cleaned in Metex P-507 and CoSpray 1028 before and after brown oxide treatment were also similar.

On December 3, 1996, the Qualification Evaluation Team consisting of members from Sandia National Laboratories and FM\&T/KC approved the use of CoSpray 1028 for use in the alkaline cleaning system. 
Appendix A

Alkaline Cleaning Process 


\section{Alkaline Cleaning Process}

Horizontally conveyorized spray cleaning system with five modules. Conveyor speeds of 40 inches per minute for modules 1 - 3 and 79 for modules 4 and 5 were used for this evaluation.

\begin{tabular}{|c|c|c|c|c|c|c|}
\hline & \multicolumn{3}{|c|}{$\begin{array}{c}\text { CoSpray } 1028 \\
(10 / 7 / 96)\end{array}$} & \multicolumn{3}{|c|}{ Metex P-507 } \\
\hline $\begin{array}{l}\text { 1. Alkaline clean (42") } \\
\text { (Tank \#Chem 5) }\end{array}$ & $\begin{array}{l}\text { PARAMETER } \\
\text { LIMITS }\end{array}$ & $\begin{array}{l}\text { ACTUAL } \\
\text { READINGS } \\
\text { Low temp } \\
\text { Low conc }\end{array}$ & $\begin{array}{l}\text { ACTUAL } \\
\text { READINGS } \\
\text { High temp } \\
\text { High conc }\end{array}$ & $\begin{array}{l}\text { PARAMETER } \\
\text { LIMITS }\end{array}$ & $\begin{array}{c}\text { ACTUAL } \\
\text { READINGS } \\
10 / 8\end{array}$ & $\begin{array}{c}\text { ACTUAL } \\
\text { READINGS } \\
10 / 15\end{array}$ \\
\hline DI water (liters) & 303 & & & 303 & & \\
\hline Temperature ( ${ }^{\circ} \mathrm{F}$ ) & $(135-145)$ & 109.9 & 139.0 & $(135-145)$ & 137.4 & 140.0 \\
\hline Time (seconds) & $7 \times 60$ & 60 & 60 & 60 & 60 & 60 \\
\hline $\begin{array}{l}\text { Spray Pressure, Upper (psi) } \\
\text { Spray Pressure, Lower (psi) } \\
\text { 2. DI water rinse (28") }\end{array}$ & & $\begin{array}{l}19 \\
19\end{array}$ & $\begin{array}{l}19 \\
19\end{array}$ & & $\begin{array}{l}19 \\
19\end{array}$ & $\begin{array}{l}19 \\
19\end{array}$ \\
\hline \multicolumn{7}{|l|}{$\begin{array}{l}\text { 3. Microetch (28") } \\
\text { (Tank \#Chem 6) }\end{array}$} \\
\hline $\begin{array}{l}\text { Sodium persulfate grams/liter } \\
\text { tank volume }\end{array}$ & $60-150$ & 121.5 & 126.2 & $60-150$ & 127.4 & 70.3 \\
\hline Sulfuric acid milliliters/liter & $10-15$ & & & $225(\mathrm{NMU})$ & & \\
\hline Copper amount (grams/liter) & $0-15$ & 11.1 & - & $0-15$ & - & 8.3 \\
\hline DI water (liters) & 145 & 145 & 145 & 145 & 145 & 145 \\
\hline Temperature ( ${ }^{\circ} \mathrm{F}$ ) & 75.81 & 77 & 76 & $75-81$ & 76 & 78 \\
\hline Time (seconds) & V. 42 & 42 & 42 & 42 & 42 & 42 \\
\hline Spray Pressure, Upper (psi) & 0 & 17 & 17 & & 17 & 17 \\
\hline Spray Pressure, Lower (psi) & Prols & 19 & 19 & & 19 & 19 \\
\hline \multicolumn{7}{|l|}{ 4. DI water rinse (28") } \\
\hline Temperature & Ambient & Ambient & Ambient & Ambient & Ambient & Ambient \\
\hline
\end{tabular}


Appendix B

Cleaner Summary 


\section{Cleaner Summary}

\section{Evaluation Plan}

The replacement being investigated for the Metex P-507 is MacDermid's CoSpray 1028. The chemical comparison is

\begin{tabular}{|l|l|}
\hline Metex P-507 & CoSpray 1028 \\
\hline $50 \%$ Sodium Metasilicate & $\begin{array}{l}15-25 \% \text { Sodium } \\
\text { Metasilicate }\end{array}$ \\
\hline $\begin{array}{l}30 \% \text { Trisodium } \\
\text { Phosphate }\end{array}$ & \\
\hline
\end{tabular}

The evaluation plan for this first involves a lab-scale study to compare the CoSpray 1028 to the Metex P-507. The measured responses will be a brown oxide test (to check the ability to remove conversion coatings), ASTM 3359-87, Method B, tape test (to measure resist adhesion), and water break (to compare surface cleanliness). If the CoSpray 1028 proves favorable, then an evaluation will be conducted with multiple material types in the Chemcut cleaning line.

\section{Data and Results}

Brown Oxide Test - Both sample types were indistinguishable in their performance. Neither cleaner was able to produce a normal brown oxide appearance after 15-minute soak in a $140^{\circ} \mathrm{F}$ solution followed by immediate immersion into the brown oxide bath. However, when copper panels (cleaned and uncleaned) were placed into the sodium persulfate-rinse-sulfuric-rinse-brown oxide, then all of the panels resulted in a nice brown oxide surface. Therefore, the critical process steps for conversion coating removal proved to be the persulfate/suilfuric combination.

Water Break Test - Again, both sample types performed the same. Both cleaners were unable to significantly improve the ability of the copper surface to hold a sheet of water. Only slight improvement was observed from analysis before and after cleaning. (CoSpray 1028: 6.5 seconds to 31 seconds and Metex P-507: 10 seconds to 24 seconds.)

Tape Test - Samples cleaned in CoSpray 1028 were very similar to the Metex P-507 for the copper samples (CoSpray 1028: 4.08 vs. Metex P-507: 4.25). However, differences were apparent with the stainless steel samples (CoSpray 1028: 1.875 vs Metex P-507: 2.875).

Flex Soak Test - Scrap flex cables were used to create samples. Samples were soaked for 15 minutes in both cleaners at $140^{\circ} \mathrm{F}$. Other samples that did not get exposed to the soaking were used for comparison. A slight matte finish was noted on the Kapton surface, but the two different samples were indistinguishable. 
The chemistries and bench-scale test results are very similar. It is therefore, my opinion that the evaluation should be continued by placement into the Chemcut cleaning line with multiple material types. Tests?

QET team reviewed the above information on 5/14/96 and agreed that the data was favorable to continue the evaluation to replace the cleaner.

May 14, 1996 
Appendix C

Scanning Auger 


\section{SCANNING AUGER}

The PHI 670xi Scanning Auger Nanoprobe (traditionally nick-named the SAM, an acronym for Scanning Auger Microprobe) is equipped with a NORAN Voyager X-Ray Detector system. This configuration allows for surface and near-surface analysis in an ultra-high vacuum environment. The Auger system employs a Field Emission electron source to provide spectroscopy information at very low beam currents. A secondary electron detector makes the system a highly proficient Scanning Electron Microscope (SEM) and, in fact, is outfitted with a variety of Image Processing software. The system's ability to alter accelerating voltages creates a natural setting for Energy Dispersive $X$-Ray analysis (EDX) using an ultra-thin Parylene window sensitive to low- $Z$ elements (carbon, oxygen, etc.). This system configuration represents the current state-of-the-art in surface analysis systems.

The Auger process involves the removal of core-level electrons from the sample matrix by impinging an electron source on the surface. These removed core-electrons cause the atoms to exist at higher (unstable) energies. One relaxation process possible to lower the atom's energy level is the creation of an Auger electron. These are very weak electrons and, consequently, possess a very short mean-free-path before expending their energy through collisions. This makes the Auger process extremely surface sensitive, on the order of two or three atomic layers. Because the Auger process involves three electrons, every element but hydrogen and helium is detectable. These electrons are detected in an ultra-high vacuum to minimize loss of signal due to interactions in the specimen chamber. Another process inherent in electron bombardment is the generation of characteristic X-rays. Again, this is a quantum mechanical relaxation method that nature employs to help stabilize high-energy atoms.

Because of their intensities, however, these X-rays can escape from greater depths within the sample. We, therefore, consider them to be near-surface occurrences.

The system also contains an ion gun used to excite argon gas which is then accelerated toward the sample to etch away superficial materials. We can do this while monitoring the elements of interest as a function of the time needed to remove them and produce something of a crosssection of the matrix. This depth-profiling technique is useful for determining the relative abundance of different elements in a relatively thin film. 
Appendix D

\section{Surface Analysis}




\begin{tabular}{|c|c|c|c|c|c|c|c|c|c|c|}
\hline \multicolumn{11}{|c|}{ SURFACE ANALYSIS } \\
\hline $\begin{array}{c}\text { Cleaner } \\
\text { Type }\end{array}$ & $\begin{array}{l}\text { Panel } \\
\text { Type }\end{array}$ & $\begin{array}{c}\text { Cospray } \\
\text { Conc/Temp }\end{array}$ & $\begin{array}{l}\text { Panel } \\
\text { Side }\end{array}$ & $\begin{array}{l}\text { Carbon } \\
\text { (C) }\end{array}$ & $\begin{array}{c}\text { Oxygen } \\
(0)\end{array}$ & $\begin{array}{c}\text { Copper } \\
\text { (Cu) }\end{array}$ & $\begin{array}{l}\text { Cloride } \\
\text { (Cl) }\end{array}$ & $\begin{array}{c}\text { Silicon } \\
\text { (Si) }\end{array}$ & $\begin{array}{l}\text { Zinc } \\
(\mathrm{Zn})\end{array}$ & $\begin{array}{c}\text { Chromium } \\
\text { (Cr) }\end{array}$ \\
\hline Cospray & Oxide & High/High & A & 14.04 & 19 & 66.88 & 0.08 & & & \\
\hline Cospray & Oxide & High/High & B & 24.78 & 19.07 & 55.64 & 0.52 & & & \\
\hline Cospray & Oxide & High/High & A & 29.14 & 16.59 & 53.83 & 0.43 & & & \\
\hline Cospray & Oxide & High/High & $\mathrm{B}$ & 38.28 & 14.28 & 46.74 & 0.69 & & & \\
\hline Cospray & Oxide & Low/Low & A & 35.73 & 14.5 & 49.06 & 0.71 & & & \\
\hline Cospray & Oxide & Low/Low & B & 37.62 & 14.83 & 46.99 & 0.56 & & & \\
\hline Cospray & Oxide & Low/Low & A & 18.01 & 21.51 & 59.95 & 0.53 & & & \\
\hline Cospray & Oxide & Low/Low & B & 2.1 & 30.16 & 67.32 & 0.42 & & & \\
\hline Cospray & Clear & High/High & A & 23.98 & 15.18 & 59.29 & 1.55 & & & \\
\hline Cospray & Clear & High/High & B & 25.86 & 17.62 & 56.39 & 0.12 & & & \\
\hline Cospray & Clear & High/High & A & 24.15 & 17.7 & 56.57 & 1.58 & & & \\
\hline Cospray & Clear & High/High & $\mathrm{B}$ & 48.35 & 10.94 & 40.49 & 0.22 & & & \\
\hline Cospray & Clear & Low/Low & A & 22 & 13.93 & 59.68 & 4.39 & & & \\
\hline Cospray & Clear & Low/Low & $A^{*}$ & 6.77 & 4.56 & 87.86 & 0.81 & & & \\
\hline Cospray & Clear & Low/Low & $B$ & 18.75 & 18.56 & 62.11 & 0.58 & & & \\
\hline Cospray & Clear & Low/Low & A & 24.49 & 15.32 & 59.82 & 0.36 & & & \\
\hline Cospray & Clear & Low/Low & $B$ & 32.38 & 15.07 & 52.03 & 0.52 & & & \\
\hline Cospray & Mixed & High/High & A & 18.18 & 23.41 & 58.35 & 0.06 & & & \\
\hline Cospray & Mixed & High/High & $B$ & 27.69 & 19.78 & 52.45 & 0.08 & & & \\
\hline Cospray & Mixed & High/High & A & 32.71 & 18.49 & 48.37 & 0.43 & & & \\
\hline Cospray & Mixed & High/High & $B$ & 18.21 & 21.02 & 60.62 & 0.15 & & & \\
\hline Cospray & Mixed & Low/Low & A & 28.14 & 17.95 & 53.27 & 0.64 & & & \\
\hline Cospray & Mixed & Low/Low & B & 36.87 & 14.61 & 48.07 & 0.45 & & & \\
\hline Cospray & Mixed & Low/Low & A & 20.03 & 19.49 & 59.73 & 0.75 & & & \\
\hline Cospray & Mixed & Low/Low & $B$ & 21.22 & 21.18 & 57.39 & 0.22 & & & \\
\hline Metex & Oxide & & A & 26.23 & 20.7 & 52.19 & 0.88 & & & \\
\hline Metex & Oxide & & B & 37.89 & 15.22 & 45.91 & 0.98 & & & \\
\hline Metex & Clear & & $A$ & 27.16 & 18.64 & 54.16 & 0.04 & & & \\
\hline Metex & Clear & & $B$ & 38.28 & 13.62 & 47.36 & 0.74 & & & \\
\hline Metex & Mixed & & A & 22.82 & 16.53 & 40.34 & 0.31 & 19.99 & & \\
\hline Metex & Mixed & & $\mathrm{B}$ & 24.49 & 17.22 & 57.73 & 0.57 & & & \\
\hline NONE & Oxide & & A & 63.34 & 12.97 & 23.52 & 0.17 & & & \\
\hline NONE & Oxide & & B & 60.78 & 13.37 & 25.43 & 0.42 & & & \\
\hline NONE & Clear & & A & 63.79 & 15.41 & 2.42 & 0.76 & & 17.62 & \\
\hline NONE & Clear & & $\mathrm{B}$ & 60.88 & 15.27 & 2.92 & 0.92 & & 19.61 & 0.4 \\
\hline NONE & Clear $^{* \star}$ & & A & 88.36 & 4.03 & 1.33 & 0.12 & & 6.16 & \\
\hline NONE & Mixed & & A & 59.77 & 15.97 & 8.75 & 0.29 & & 13.9 & 1.32 \\
\hline NONE & Mixed & & $\mathrm{B}$ & 70.9 & 12.06 & 5.13 & 0.32 & & 11.18 & 0.41 \\
\hline
\end{tabular}

*Sputtered

*A Area previousiy covered with label. 
Appendix E Tabulated Data

28 


\section{DATA TABLES}

\begin{tabular}{|c|c|c|c|c|c|c|c|c|}
\hline \multicolumn{8}{|c|}{ SOLUTION PARAMETERS AND MATERIAL TYPE VS ADHESION } \\
\hline PANEL \# & $\begin{array}{c}\text { MATERIAL } \\
\text { TYPE }\end{array}$ & $\begin{array}{c}\text { COSPRAY } \\
\text { CONC \& } \\
\text { TEMP }\end{array}$ & SCRIBE 1 & SCRIBE 2 & SCRIBE 3 & AVG & $\begin{array}{c}\text { AVG } \\
\text { (total) }\end{array}$ & $\begin{array}{c}\text { STANDARD } \\
\text { DEVIATION }\end{array}$ \\
\hline 4 & MIXED & Low & 4 & 4 & 5 & 4.33 & & \\
\hline 5 & MIXED & Low & 4 & 4 & 5 & 4.33 & 4.17 & 0.50 \\
\hline 6 & MIXED & Low & 4 & 3.5 & 4 & 3.83 & & \\
\hline 4 & CLEAR & Low & 5 & 5 & 5 & 5.00 & & \\
\hline 5 & CLEAR & Low & 4.5 & 5 & 4.5 & 4.67 & 4.56 & 0.68 \\
\hline 6 & CLEAR & Low & 4 & 3 & 5 & 4.00 & & \\
\hline 4 & DARK & Low & 4.5 & 5 & 5 & 4.83 & & \\
\hline 5 & DARK & Low & 5 & 4.5 & 5 & 4.83 & 4.67 & 0.35 \\
\hline 6 & DARK & Low & 4 & 4.5 & 4.5 & 4.33 & & \\
\hline 12 & MIXED & High & 4.5 & 5 & 3.5 & 4.33 & & \\
\hline 13 & MIXED & High & 4.5 & 4 & 4.5 & 4.33 & 4.44 & 0.46 \\
\hline 14 & MIXED & High & 5 & 4.5 & 4.5 & 4.67 & & \\
\hline 12 & CLEAR & High & 4.5 & 4.5 & 4.5 & 4.50 & & \\
\hline 13 & CLEAR & High & 3 & 3 & 3.5 & 3.17 & 3.89 & \\
\hline 14 & CLEAR & High & 4 & 4 & 4 & 4.00 & & 0.60 \\
\hline 12 & DARK & High & 4 & 3.5 & 4 & 3.83 & & \\
\hline 13 & DARK & High & 5 & 5 & 5 & 5.00 & 4.11 & 0.70 \\
\hline 14 & DARK & High & 3.5 & 3.5 & 3.5 & 3.50 & & \\
\hline
\end{tabular}




\section{WEIGHT LOSS DATA AT A FIXED CONVEYOR SPEED}

\begin{tabular}{|c|c|c|c||c|c|c|c|}
\hline \multicolumn{7}{|c|}{ MATERIAL TYPE AND SOLUTION PARAMETERS VS PANEL WEIGHT LOSS } \\
\hline \multirow{2}{*}{ PANEL } & COSPRAY & MATERIAL & SPEED & $\begin{array}{c}\text { PANEL WEIGHT } \\
\text { (grams) }\end{array}$ & WEIGHT LOSS & AVG \\
\cline { 3 - 8 } NUMBER & CONC/TEMP & TYPE & & $\begin{array}{c}\text { Before } \\
\text { Clean }\end{array}$ & $\begin{array}{c}\text { After } \\
\text { Clean }\end{array}$ & (Before - After) & \\
\hline 1 & Low/Low & Mixed & 40 & 99.10 & 97.84 & 1.26 & \\
\hline 2 & Low/Low & Mixed & 40 & 99.12 & 97.80 & 1.32 & 1.23 \\
\hline 3 & Low/Low & Mixed & 40 & 99.12 & 98.01 & 1.11 & \\
\hline 1 & Low/Low & Clear & 40 & 93.48 & 92.15 & 1.33 & 1.31 \\
\hline 2 & Low/Low & Clear & 40 & 94.76 & 93.45 & 1.28 \\
\hline 3 & Low/Low & Clear & 40 & 95.04 & 93.85 & 1.19 & \\
\hline 1 & Low/Low & Dark & 40 & 143.13 & 141.73 & 1.40 & \\
\hline 2 & Low/Low & Dark & 40 & 142.08 & 140.60 & 1.48 & 1.38 \\
\hline 3 & Low/Low & Dark & 40 & 144.03 & 142.78 & 1.25 & \\
\hline 9 & High/High & Mixed & 40 & 99.92 & 98.55 & 1.37 & \\
\hline 10 & High/High & Mixed & 40 & 99.67 & 98.36 & 1.31 & 1.32 \\
\hline 11 & High/High & Mixed & 40 & 99.03 & 97.76 & 1.27 & \\
\hline 9 & High/High & Clear & 40 & 98.03 & 96.54 & 1.49 & \\
\hline 10 & High/High & Clear & 40 & 95.66 & 94.09 & 1.57 & 1.53 \\
\hline 11 & High/High & Clear & 40 & 95.23 & 93.69 & 1.54 & \\
\hline 9 & High/High & Dark & 40 & 145.78 & 144.22 & 1.56 & \\
\hline 10 & High/High & Dark & 40 & 143.08 & 141.43 & 1.65 & 1.60 \\
\hline 11 & High/High & Dark & 40 & 141.12 & 139.52 & 1.60 & \\
\hline
\end{tabular}




\begin{tabular}{|c|c|c|c|c|c|c|c|c|c|c|}
\hline \multicolumn{11}{|c|}{$\begin{array}{l}\text { COSPRAY-CLEANED COPPER } \\
\text { AND CONVEYOR SPEED VS PAN }\end{array}$} \\
\hline \multirow{3}{*}{$\frac{\text { PANEL }}{\#}$} & \multirow{3}{*}{$\begin{array}{c}\text { SPRAY } \\
\text { MANIFOLD }\end{array}$} & \multirow{3}{*}{$\begin{array}{c}\begin{array}{c}\text { CONVEY } \\
\text { OR }\end{array} \\
\text { SPEED }\end{array}$} & \multicolumn{4}{|c|}{$\begin{array}{c}\text { HIGH SOLUTION CONCENTRATION \& } \\
\text { TEMPERATURE }\end{array}$} & \multicolumn{4}{|c|}{$\begin{array}{c}\text { LOW SOLUTION CONCENTRATION \& } \\
\text { TEMPERATURE }\end{array}$} \\
\hline & & & \multicolumn{2}{|c|}{$\begin{array}{l}\text { PANEL WEIGHT } \\
\text { (grams) }\end{array}$} & \multirow{2}{*}{\begin{tabular}{|c|} 
WEIGHT \\
LOSS \\
(Before - \\
After) \\
\end{tabular}} & \multirow[t]{2}{*}{ AVG } & \multicolumn{2}{|c|}{$\begin{array}{l}\text { PANEL WEIGHT } \\
\text { (grams) }\end{array}$} & \multirow{2}{*}{$\begin{array}{c}\text { WEIGHT } \\
\text { LOSS } \\
\text { (Before - } \\
\text { After) }\end{array}$} & \multirow[t]{2}{*}{ AVG } \\
\hline & & & $\begin{array}{l}\text { Before } \\
\text { Clean }\end{array}$ & $\begin{array}{l}\text { After } \\
\text { Clean }\end{array}$ & & & $\begin{array}{l}\text { Before } \\
\text { Clean }\end{array}$ & $\begin{array}{l}\text { After } \\
\text { Clean }\end{array}$ & & \\
\hline 101 & Top & 10 & 140.94 & 139.00 & 1.94 & & 139.05 & 134.33 & 472 & $f^{2}$ \\
\hline 102 & Top & 10. & 141.75 & 139.30 & 2.45 & 2.19 & 139.34 & 134.66 & 4.68 & 4.70 \\
\hline 103 & Top & 30 & 185.21 & 184.50 & 0.71 & & 184.54 & 183.12 & 1.42 & \\
\hline 104 & Top & 30 & 149.25 & 148.43 & 0.82 & 0.77 & 148.47 & 147.07 & 1.40 & 1.41 \\
\hline 105 & Top & 40 & 142.42 & 141.88 & 0.54 & 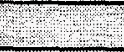 & 141.93 & 140.86 & 1.07 & 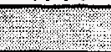 \\
\hline 106 & Top & 40 & 157.98 & 157.42 & 0.56 & 0.55 & 157.47 & 156.40 & 1.07 & 1.07 \\
\hline 107 & Top & 75 & 148.51 & 148.19 & 0.32 & & 148.23 & 147.60 & 0.63 & \\
\hline 108 & Top & 75 & 155.35 & 155.00 & 0.35 & 0.33 & 155.02 & 154.43 & 0.59 & 0.61 \\
\hline 109 & Top & 100 & 148.66 & 148.38 & 0.28 & & 148.42 & 147.94 & 0.48 & \\
\hline 110 & Top & 100 & 149.67 & 149.37 & 0.30 & 0.29 & 149.39 & 148.90 & 0.49 & 0.48 \\
\hline 201 & Bottom & 10 & 145.65 & 142.61 & 3.04 & & 142.62 & 137.00 & 5.62 & \\
\hline 202 & Bottom & 10 & 135.05 & 132.57 & 2.48 & 2.76 & 132.60 & 127.11 & 5.49 & 5.56 \\
\hline 203 & Bottom & 30 & 143.05 & 142.31 & 0.74 & & 142.35 & 140.75 & 1.60 & \\
\hline 204 & Bottom & 30 & 149.65 & 148.90 & 0.75 & 0.75 & 148.95 & 147.32 & 1.63 & 1.61 \\
\hline 205 & Bottom & 40 & 140.62 & 140.10 & 0.52 & & 140.12 & 138.83 & 1.29 & \\
\hline 206 & Bottom & 40 & 143.17 & 142.58 & 0.59 & 0.55 & 142.65 & 141.38 & 1.27 & 1.28 \\
\hline 207 & Bottom & 75 & 149.48 & 149.14 & 0.34 & & 149.15 & 148.45 & 0.70 & 1.20 \\
\hline 208 & Bottom & 75 & 143.29 & 142.92 & 0.37 & 0.36 & 142.96 & 142.30 & 0.66 & 0.68 \\
\hline 209 & Bottom & 100 & 144.12 & 143.88 & 0.24 & & 143.90 & 143.32 & 0.58 & \\
\hline 210 & Bottom & 100 & 141.30 & 141.02 & 0.28 & 0.26 & 140.98 & 140.46 & 0.52 & 0.55 \\
\hline
\end{tabular}




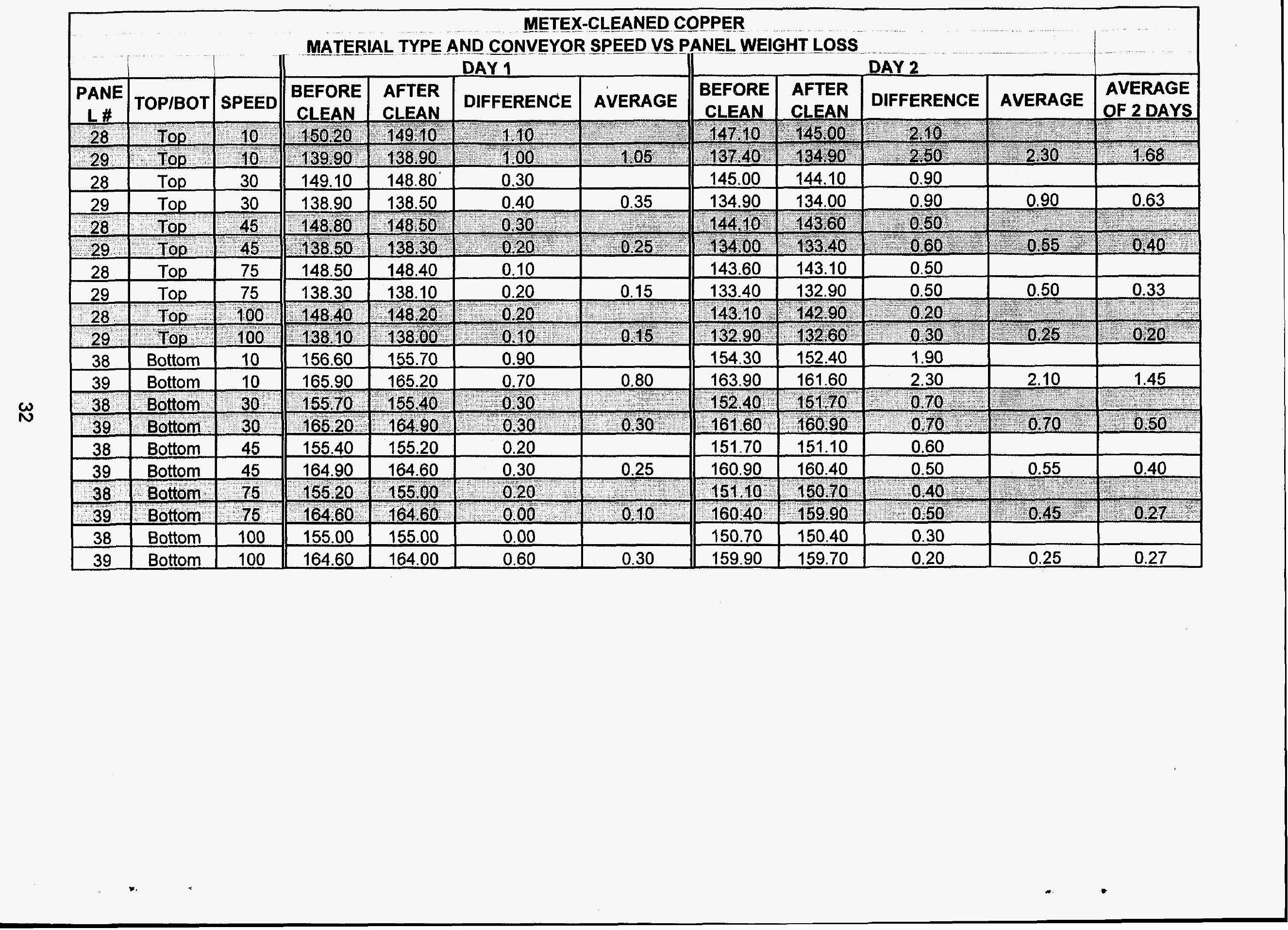

